\title{
Simulations of organic aerosol concentrations during springtime in the Guanzhong Basin, China
}

\author{
Tian Feng ${ }^{1,2}$, Guohui Li $^{2}$, Junji Cao ${ }^{2}$, Naifang Bei ${ }^{1,2}$, Zhenxing Shen ${ }^{3}$, Weijian Zhou ${ }^{2}$, Suixin Liu ${ }^{2}$, Ting Zhang ${ }^{2}$, \\ Yichen Wang $^{2}$, Ru-jin Huang ${ }^{2}$, Xuexi Tie ${ }^{2}$, and Luisa T. Molina ${ }^{4,5}$ \\ ${ }^{1}$ School of Human Settlements and Civil Engineering, Xi' an Jiaotong University, Xi' an, Shaanxi, China \\ ${ }^{2}$ Key Lab of Aerosol Chemistry and Physics, State Key Laboratory of Loess and Quaternary Geology, \\ Institute of Earth Environment, Chinese Academy of Sciences, Xi' an, China \\ ${ }^{3}$ School of Energy and Power Engineering, Xi' an Jiaotong University, Xi' an, Shaanxi, China \\ ${ }^{4}$ Molina Center for Energy and the Environment, La Jolla, CA, USA \\ ${ }^{5}$ Department of Earth, Atmospheric and Planetary Sciences, Massachusetts Institute of Technology, Cambridge, MA, USA \\ Correspondence to: Guohui Li (ligh@ieecas.cn) and Junji Cao (jjcao@ieecas.cn)
}

Received: 15 March 2016 - Published in Atmos. Chem. Phys. Discuss.: 21 April 2016

Revised: 14 July 2016 - Accepted: 15 July 2016 - Published: 9 August 2016

\begin{abstract}
The organic aerosol (OA) concentration is simulated in the Guanzhong Basin, China from 23 to 25 April 2013 utilizing the WRF-CHEM model. Two approaches are used to predict OA concentrations: (1) a traditional secondary organic aerosol (SOA) module; (2) a non-traditional SOA module including the volatility basis-set modeling method in which primary organic aerosol (POA) is assumed to be semivolatile and photochemically reactive. Generally, the spatial patterns and temporal variations of the calculated hourly near-surface ozone and fine particle matters agree well with the observations in Xi' an and surrounding areas. The model also yields reasonable distributions of daily $\mathrm{PM}_{2.5}$ and elemental carbon (EC) compared to the filter measurements at 29 sites in the basin. Filter-measured organic carbon (OC) and EC are used to evaluate OA, POA, and SOA using the OC / EC ratio approach. Compared with the traditional SOA module, the non-traditional module significantly improves SOA simulations and explains about $88 \%$ of the observed SOA concentration. Oxidation and partitioning of POA treated as semivolatile constitute the most important pathway for the SOA formation, contributing more than $75 \%$ of the SOA concentrations in the basin. Residential emissions are the dominant anthropogenic OA source, constituting about $50 \%$ of OA concentrations in urban and rural areas and $30 \%$ in the background area. The OA contribution from transportation emissions decreases from $25 \%$ in urban areas
\end{abstract}

to $20 \%$ in the background area, and the industry emission OA contribution is less than $6 \%$.

\section{Introduction}

Atmospheric aerosol or fine particulate matter $\left(\mathrm{PM}_{2.5}\right)$ influences regional and global climate directly by absorbing and scattering the solar radiation and indirectly by serving as cloud condensation nuclei (CCN) and ice nuclei (IN) to modify cloud properties (Seinfeld and Pandis, 2006). Elevated aerosol concentrations also exert adverse impacts on ecosystems and human health, and reduce the visibility of the atmosphere to cause the haze formation, impairing air quality (Cao et al., 2012a, b; Greenwald et al., 2006; Seinfeld and Pandis, 2006).

Organic aerosol (OA) constitutes one of the most important components of $\mathrm{PM}_{2.5}$ in the atmosphere, with the mass contribution to $\mathrm{PM}_{2.5}$ ranging from 20 to $90 \%$ (Kanakidou et al., 2005; Zhang et al., 2007). Traditionally, OA is categorized into primary and secondary OAs on the basis of its source and/or formation, referred to as POA and SOA, respectively. POA is emitted into the atmosphere directly, while SOA forms through chemical reactions of precursors in the atmosphere. Volatile organic compounds (VOCs) emitted from anthropogenic or biogenic sources undergo a series of oxidation and gas-particle partitioning to yield SOA, 
Table 1. Previous results about different OA contributions.

\begin{tabular}{|c|c|c|c|}
\hline Reference & Time period & City & Description \\
\hline \multirow[t]{4}{*}{ Huang et al. (2014) } & 5-25 January 2013 & Beijing & $\mathrm{OA} / \mathrm{PM}_{2.5}(40.7 \%)$ \\
\hline & & Shanghai & $\mathrm{OA} / \mathrm{PM}_{2.5}(48.0 \%)$ \\
\hline & & Guangzhou & $\mathrm{OA} / \mathrm{PM}_{2.5}(33.1 \%)$ \\
\hline & & Xi'an & $\mathrm{OA} / \mathrm{PM}_{2.5}(30.5 \%)$ \\
\hline Sun et al. (2012) & 26 June-28 August 2011 & Beijing & OOA / OA $(64 \%)$ \\
\hline Sun et al. (2013) & Summer 2012 & Beijing & $\left(\mathrm{OA}\right.$ in $\left.\mathrm{NR}-\mathrm{PM}_{1}\right) / \mathrm{NR}-\mathrm{PM}_{1}(52 \%)$ \\
\hline Cao et al. (2013) & MIRAGE-Shanghai 2009 & Shanghai & $\mathrm{OC} / \mathrm{TC}(31 \%)$ \\
\hline
\end{tabular}

which has been regarded as a traditional pathway of the SOA formation (Odum et al., 1996; Pankow, 1994). Recently, semivolatile POA has been identified to be oxidized continuously to produce SOA in laboratory studies (Lipsky and Robinson, 2006; Shrivastava et al., 2006). The mechanism has been parameterized into chemical transport models (Dzepina et al., 2009; Lane et al., 2008; Li et al., 2011b; Murphy and Pandis, 2009; Robinson et al., 2007; Shrivastava et al., 2008; Tsimpidi et al., 2010), significantly improving SOA simulations and capable of closing the gap between the calculated and observed SOA concentrations.

China has been suffering severe air pollution caused by rapid industrialization and urbanization (Cao et al., 2007, 2005, 2012b; Guinot et al., 2007; He et al., 2015, 2001; Shen et al., 2009; Tie et al., 2015; Yang et al., 2011; Zhang et al., 2015, 2013). Numerous studies have shown that OA plays an important role in the haze formation in China. Huang et al. (2014) have reported that OA constitutes a major fraction (30-50\%) of the total $\mathrm{PM}_{2.5}$ in Beijing, Shanghai, Guangzhou, and Xi' an during severe haze pollution events (Table 1), and SOA contributes $44-71 \%$ of OA mass concentrations. Using the ACSM (aerosol chemical speciation monitor) measurements analyzed by PMF (positive matrix factorization), Sun et al. (2012) have shown that the oxygenated organic aerosol (OOA, a surrogate of SOA) dominates OA composition in Beijing, with a contribution of $64 \%$ on average from 26 June to 28 August 2011. Sun et al. (2013) have found that OA accounts for $52 \%$ of the total nonrefractory submicron particulate matters mass loading measured by ACMS during wintertime 2012 in Beijing. Cao et al. (2013) have reported that secondary organic carbon constitutes $31 \%$ of the total carbon utilizing an EC tracer system and isotope mass balance calculations during the MIRAGEShanghai (Megacities Impact on Regional and Global Environment) campaign in 2009.

The Guanzhong Basin (GZB) is located in northwestern China and nestled between the Qinling Mountains in the south and the Loess Plateau in the north (Fig. 1), with a warm-humid climate. The rapid increasing industries and city expansions, as well as the unique topography, have caused frequent occurrence of haze events in GZB (Shen et al., 2009, 2008). Measurements have shown that carbonaceous aerosols (OA and EC) constitute 48.6 and $45.9 \%$ of

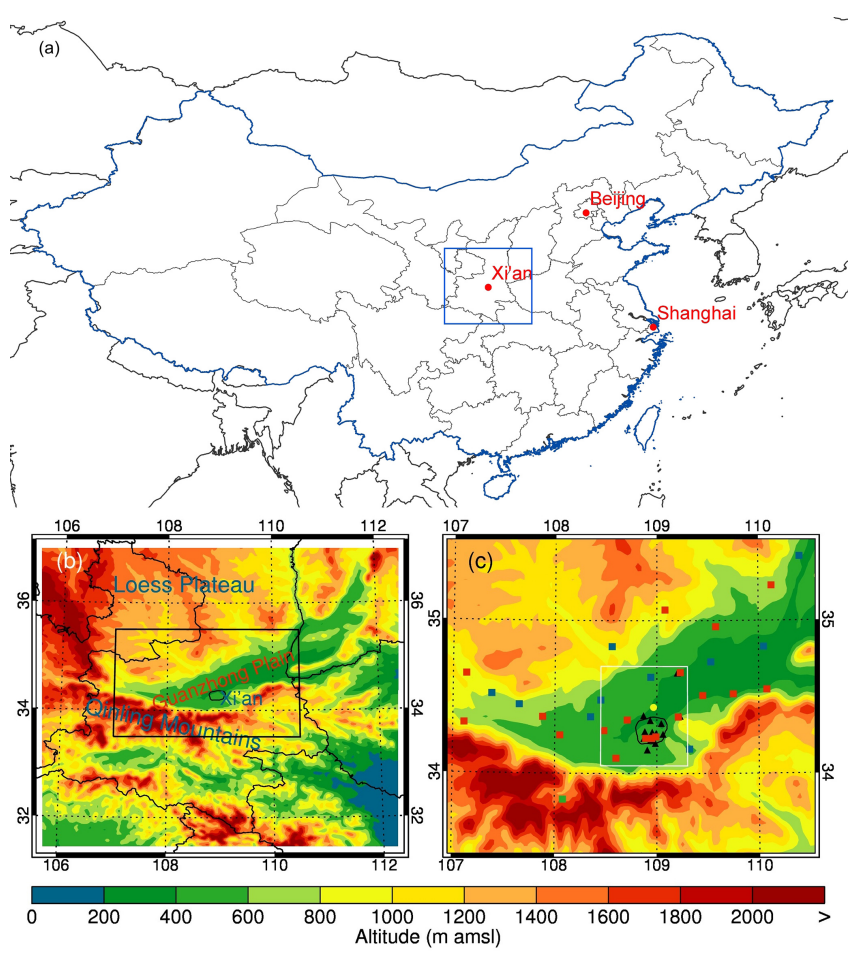

Figure 1. Map showing (a) the location of Xi'an in China, (b) WRF-CHEM model simulation domain with topography and (c) geographic distributions of 13 ambient air quality monitoring stations (black triangles) and 29 enhanced sites with filter measurements (squares). The filled red, blue, and green squares represent the urban, rural, and background sites, respectively. The area surrounded by the white line in panel (c) is defined as $\mathrm{Xi}$ ' an and surrounding areas. The black circle in panels (b) and (c) shows the ring expressway of Xi'an. The yellow spot is the location of the Jinghe meteorological station.

$\mathrm{PM}_{2.5}$ mass concentration in fall and winter, respectively, in Xi' an, the largest city of GZB (Cao et al., 2005). Abundant OA has been reported to be directly emitted into the atmosphere from anthropogenic emissions, such as residential and transportation sources in GZB (Cao et al., 2005). High SOA levels have been observed in GZB during wintertime (Huang et al., 2014). However, the source and formation of OA, and especially SOA, in GZB, still remain obscure. 
During the period from 20 to 26 April 2013, a field campaign has been conducted to identify the OA distribution and sources in GZB and, due to occurrence of precipitation on the first 3 days, an episode during 23-25 April has been simulated to identify the OA sources in this study. Daily filter measurements at 29 sites in GZB have been collected, and $\mathrm{EC}$ and $\mathrm{OC}$ have been analyzed in $\mathrm{PM}_{2.5}$. In general, the EC / OC ratio approach can be used to evaluate the OA, POA, and SOA concentrations using the filter-measured OC and EC (Strader, 1999; Cao et al., 2003, 2004). Therefore, those measurements provide a good opportunity for better understanding OA sources and SOA formation in GZB.

The objective of the present study is to examine the formation and source apportionments of OA and SOA in GZB during 3 days in the spring of 2013 using the WRF-CHEM model. The WRF-CHEM model and its configuration are described in Sect. 2. The model results and discussions are presented in Sect. 3, and the conclusions are summarized in Sect. 4.

\section{Model and method}

The WRF-Chem model and the SOA modules in the present study are nearly the same as those in Li et al. (2011b), which are briefly introduced in Sect. 2.1 and 2.2 for convenience.

\subsection{WRF-CHEM model}

A specific version of the WRF-CHEM model (Grell et al., 2005) developed by Li et al. (2010, 2011a, b, 2012) at Molina Center for Energy and the Environment (MCE2) is utilized to investigate the OA formation in GZB. This version employs a flexible gas-phase chemical module and the CMAQ (version 4.6) aerosol module developed by US EPA (Binkowski and Roselle, 2003). The dry deposition of chemical species is parameterized according to Wesely (1989) and the wet deposition follows the method in CMAQ. The FTUV module (Li et al., 2005; Tie et al., 2003) considering the impacts of aerosols and clouds on photochemistry is used to calculate the photolysis rates. The ISORROPIA version 1.7 (Nenes et al., 1998) is employed to the WRF-CHEM model to simulate the inorganic aerosols.

\subsection{Secondary organic aerosol modules}

Two kinds of SOA modules are utilized in the WRF-CHEM model simulations: a traditional two-product SOA module (T2-SOA module) and a non-traditional SOA module (NTSOA module) (Li et al., 2011b).

In the T2-SOA module, SOA concentrations are predicted from the oxidation of six lumped organic species, including alkanes, alkenes, cresol, high-yield aromatics, low-yield aromatics, and monoterpenes, following the method developed by Schell et al. (2001).
The NT-SOA module simulates SOA formation based on the volatility basis-set (VBS) method (Donahue et al., 2006; Robinson et al., 2007). In the module, the POA is distributed in logarithmically spaced volatility bins and assumed to be semivolatile and photochemically reactive (Li et al., 2011b). A total of nine surrogate species with saturation concentration ranging from $10^{-2}$ to $10^{6} \mu \mathrm{g} \mathrm{m}^{-3}$ at room temperature are selected to represent POA components following (Shrivastava et al., 2008). The SOA formation from glyoxal and methylglyoxal is parameterized as a first-order irreversible uptake by aerosol particles with a reactive uptake coefficient of $3.7 \times 10^{-3}$ (Volkamer et al., 2007; Zhao et al., 2006). Detailed information about T2-SOA and NT-SOA modules can be found in Li et al. (2011b).

\subsection{Model configuration}

In this study, a 3-day episode from 23 to 25 April 2013 is simulated in association with the filter measurements of $\mathrm{PM}_{2.5}$, OC, and EC in GZB. The model is configured with a horizontal grid spacing of $3 \mathrm{~km}$ and $200 \times 200$ grid cells which is centered at $34.25^{\circ} \mathrm{N}$ and $109^{\circ} \mathrm{E}$ (Fig. 1). In the vertical direction, we use 35 levels in a stretched vertical grid with spacing ranging from $50 \mathrm{~m}$ near the surface to $500 \mathrm{~m}$ at $2.5 \mathrm{~km}$ above ground level and $1 \mathrm{~km}$ above $14 \mathrm{~km}$. The physics and dynamics of the configuration adopt the microphysics scheme of Hong and Lim (2006), the Yonsei University planetary boundary layer scheme (Hong et al., 2006), the land surface scheme of 5-layer thermal diffusion (Dudhia, 1996), the Dudhia shortwave scheme (Dudhia, 1989), and the rapid radiative transfer model (RRTM) longwave scheme (Mlawer et al., 1997). No cumulus parameterization is used due to the high horizontal resolution. The distance of GZB from the boundaries of the domain is about $150-200 \mathrm{~km}$ (50-70 grid cells). The NCEP $1^{\circ} \times 1^{\circ}$ reanalysis data are used for the meteorological initial and boundary conditions. In the present study, the NCEP ADP Global Surface Observational Weather Data (http://rda.ucar.edu/) in GZB are assimilated in the WRF-CHEM model simulations using the four-dimension data assimilation (FDDA) to improve the simulation of meteorological fields. The chemical initial and boundary conditions are interpolated from Model for OZone And Related chemical Tracers (MOZART) output with a $6 \mathrm{~h}$ interval (Horowitz et al., 2003). The spin-up time for the simulation is 1 day.

The anthropogenic emission inventory (EI) including agriculture, industry, power plant, residential, and transportation sources is developed by Zhang et al. (2009). The temporal resolution of the emissions is $1 \mathrm{~h}$, and a weekly and a diurnal cycle are included in the emissions. Figure 2 shows the monthly POA and VOC emissions in GZB during April along with the Xi' an urban area. Large anthropogenic emissions are concentrated in $\mathrm{Xi}$ ' an and surrounding areas. Table 2 presents the primary organic carbon and volatile organic compounds emissions from anthropogenic sources in 

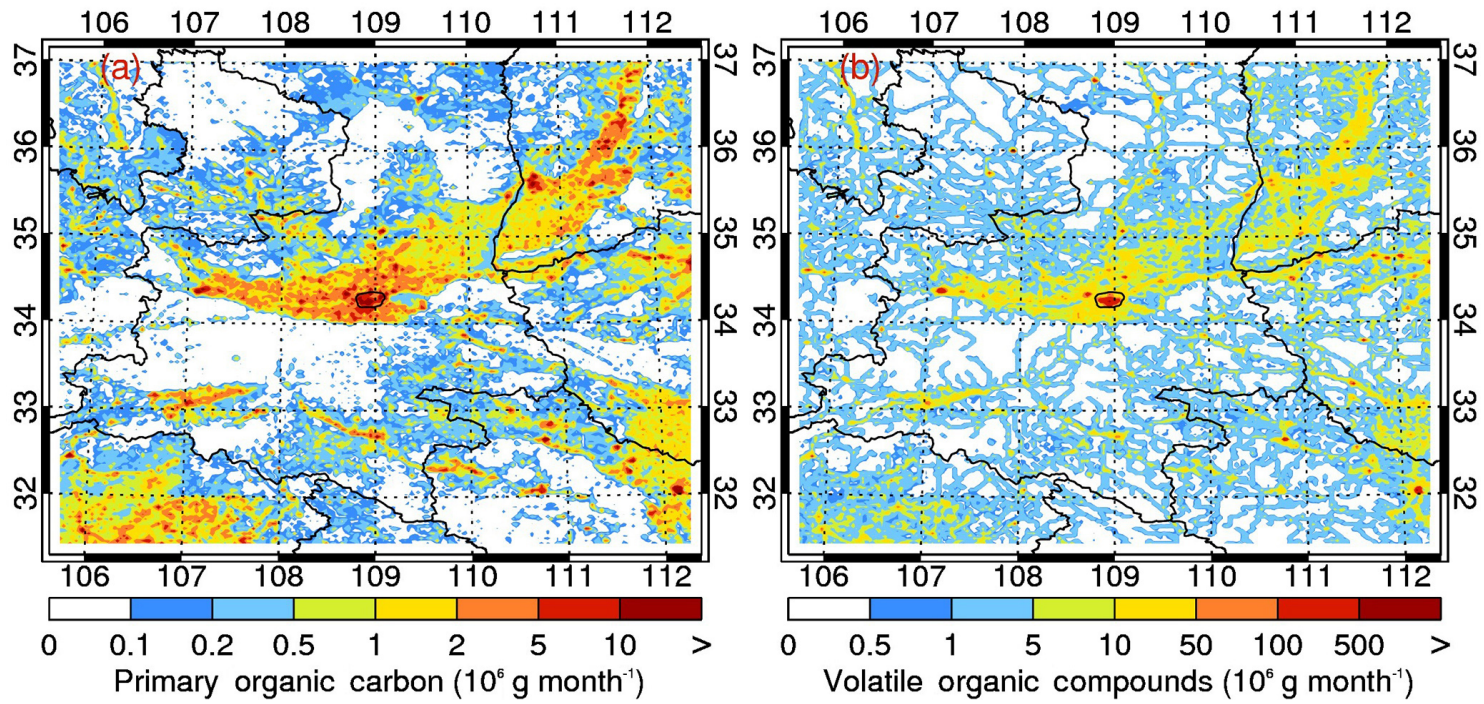

Figure 2. Geographic distributions of anthropogenic emissions of (a) primary organic aerosol and (b) volatile organic compounds in the simulation domain. The black lines present provincial boundaries in China.

Table 2. Primary organic carbon and volatile organic compounds emissions from anthropogenic sources in Xi' an and surrounding areas (the area surrounded by the white line in Fig. 1c) in April.

\begin{tabular}{lrr}
\hline $\begin{array}{l}\text { Anthropogenic emission } \\
\text { sectors }\end{array}$ & $\begin{array}{r}\text { Primary organic } \\
\text { carbon }(\mathrm{Mg})\end{array}$ & $\begin{array}{r}\text { Volatile organic } \\
\text { compounds }(\mathrm{Mg})\end{array}$ \\
\hline Industry & 2486.0 & 7634.5 \\
Power plant & 0.0 & 81.7 \\
Residential & 4988.8 & 1704.4 \\
Transportation & 318.5 & 736.9 \\
\hline
\end{tabular}

Xi'an and surrounding areas in April. The POA from the transportation source and biomass burning is redistributed following Tsimpidi et al. (2010). The MEGAN model is used to on-line calculate the biogenic emissions in the model (Guenther et al., 2006).

\subsection{Statistical methods for comparisons}

The mean bias (MB), root mean square error (RMSE), and index of agreement (IOA) are used to evaluate the model performance in simulating gas-phase species and aerosols.

$$
\begin{aligned}
& \mathrm{MB}=\frac{1}{N} \sum_{i=1}^{N}\left(P_{i}-O_{i}\right) \\
& \mathrm{RMSE}=\left[\frac{1}{N} \sum_{i=1}^{N}\left(P_{i}-O_{i}\right)^{2}\right]^{\frac{1}{2}} \\
& \mathrm{IOA}=1-\frac{\sum_{i=1}^{N}\left(P_{i}-O_{i}\right)^{2}}{\sum_{i=1}^{N}\left(\left|P_{i}-\bar{O}\right|+\left|O_{i}-\bar{O}\right|\right)^{2}},
\end{aligned}
$$

where $P_{i}$ and $O_{i}$ are the predicted and observed variables, respectively. $N$ is the total number of the predictions for com- parison and $\bar{O}$ donates the average of the observation. The IOA ranges from 0 to 1 , with 1 showing a perfect agreement of the prediction with the observation.

\subsection{Measurement data}

The measurement data include temperature, relative humidity, and wind observations at the Jinghe meteorological station, hourly near-surface $\mathrm{O}_{3}$ and $\mathrm{PM}_{2.5}$ concentrations at ambient monitoring stations in Xi' an and surrounding areas, and daily filter measurements of $\mathrm{PM}_{2.5}, \mathrm{OC}$, and $\mathrm{EC}$ at 29 sites in GZB during the field campaign and at the Institute of Earth Environment, Chinese Academy of Sciences (IEECAS) in Xi' an during the springtime from 2009 to 2013. The observation sites are categorized into three types with regard to their locations: 18 urban sites, 10 rural sites, and 1 background site as shown in Fig. 1b. The background site is located in the Qinling Mountains, which are far away from the residential areas. The daily filter samples are obtained on prefired $\left(900^{\circ} \mathrm{C}, 3 \mathrm{~h}\right) 47 \mathrm{~mm}$ Whatman QM-A quartz-fiber filters by mini-volume air samplers (Airmetrics, Eugene, OR) at $5 \mathrm{~L} \mathrm{~min}^{-1}$ flow rates.

The measured $\mathrm{PM}_{2.5}$ and $\mathrm{OC}$ concentrations averaged over the 29 sites in GZB during the study period are compared with the springtime $\mathrm{PM}_{2.5}$ and $\mathrm{OC}$ observations at the IEECAS site from 2009 to 2013 in Fig. 3, along with the standard deviations. The springtime $\mathrm{PM}_{2.5}$ concentrations at the IEECAS site from 2009 to 2013 remain about $150 \mu \mathrm{g} \mathrm{m}^{-3}$ with small fluctuations, which is close to the $\mathrm{PM}_{2.5}$ level during the study period. The springtime OC concentrations at the IEECAS site from 2009 to 2013 vary from 14 to $22 \mu \mathrm{g} \mathrm{m}^{-3}$. The mean OC concentration during the study period is about $19 \mathrm{\mu g} \mathrm{m}^{-3}$, close to the medium level at the IEECAS site 

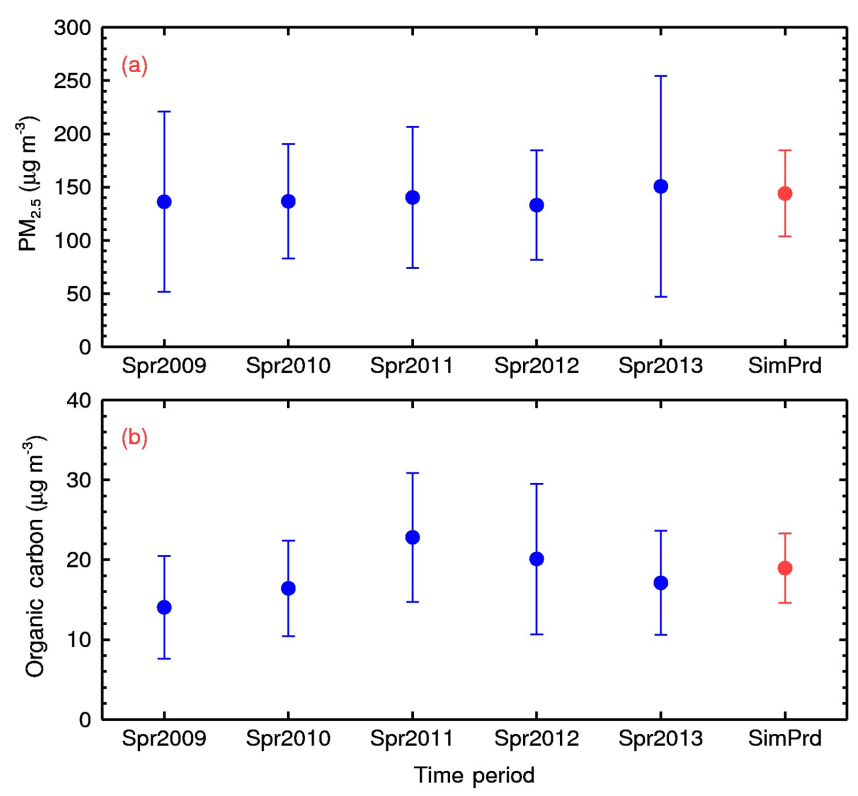

Figure 3. Plot showing the means and standard deviations of observed springtime $\mathrm{PM}_{2.5}$ and organic carbon concentrations from 2009 to 2013 (blue), along with the filter measurements during the simulation period in this study (SimPrd, red).

from 2009 to 2013. Hence, the $\mathrm{PM}_{2.5}$ and OC levels during the study period can well represent the springtime $\mathrm{PM}_{2.5}$ and OC pollution in GZB within recent years.

The OC / EC ratio approach has been widely employed to evaluate the $\mathrm{OA}$ concentration from the filter-measured OC and EC concentrations (Strader, 1999; Cao et al., 2003, 2004). The following method is used to derive the measured POA, SOA, and OA mass concentrations from EC and OC filter measurements:

$$
\begin{aligned}
& \mathrm{POC}=\mathrm{EC} \times(\mathrm{POC} / \mathrm{EC} \text { ratio }) \\
& \mathrm{SOC}=\mathrm{OC}-\mathrm{POC} \\
& \mathrm{POA}=\mathrm{POC} \times(\mathrm{POA} / \mathrm{POC} \text { ratio }) \\
& \mathrm{SOA}=\mathrm{SOC} \times(\mathrm{SOA} / \mathrm{SOC} \text { ratio }) \\
& \mathrm{OA}=\mathrm{POA}+\mathrm{SOA} .
\end{aligned}
$$

Cao et al. (2007) have analyzed the OC and EC concentrations in 14 cities over China in 2003 and proposed primary OC / EC ratios for different cities in China during winter and summer (Table 3). Numerous studies have been performed to investigate the POA / POC and SOA / SOC ratios (Aiken et al., 2008; Yu et al., 2009; Yu, 2011), which can be used to obtain OA concentrations from measured EC and OC concentrations. In this study, the POC / EC, POA / POC, and SOA / SOC ratios are assumed to be 2.4, 1.2, and 1.6, respectively, based on the previous studies (Cao et al., 2007; Aiken et al., 2008; Yu et al., 2009; Yu, 2011). It is worth to note that these assumed values might affect the model-measurement comparisons.
Table 3. The primary OC / EC ratios over China in 2003 proposed by Cao et al. (2007).

\begin{tabular}{rrrrrrr}
\hline & \multicolumn{2}{c}{ Northern cities } & & \multicolumn{2}{c}{ Southern cities } \\
\cline { 2 - 3 } \cline { 5 - 6 } & Winter & Summer & & Winter & Summer \\
\hline POC / EC ratio & 2.81 & 1.99 & & 2.10 & 1.29 \\
\hline
\end{tabular}

Using the measured $\mathrm{EC}$ and $\mathrm{OC}$ concentrations, the SOA / EC ratio is calculated:

$$
\begin{aligned}
&(\mathrm{SOA} / \mathrm{EC} \text { ratio })=(\mathrm{SOA} / \mathrm{SOC} \text { ratio }) \times(\mathrm{SOC} / \mathrm{EC} \text { ratio }) \\
&=(\mathrm{SOA} / \mathrm{SOC} \text { ratio }) \times[(\mathrm{OC}-\mathrm{POC}) / \mathrm{EC}] \\
&=(\mathrm{SOA} / \mathrm{SOC} \text { ratio }) \times[(\mathrm{OC} / \mathrm{EC} \text { ratio }) \\
&-(\mathrm{POC} / \mathrm{EC} \text { ratio })]
\end{aligned}
$$

and the POA / EC ratio is derived as follows:

$$
\begin{aligned}
(\mathrm{POA} / \mathrm{EC} \text { ratio })= & (\mathrm{POA} / \mathrm{POC} \text { ratio }) \\
& \times(\mathrm{POC} / \mathrm{EC} \text { ratio }) .
\end{aligned}
$$

\section{Results and discussions}

\subsection{Model performance}

The meteorological fields are of essential importance for the simulation of chemical species concentrations in time evolution and spatial distribution (Bei et al., 2008, 2010, 2012). Model performance is validated using the hourly ozone $\left(\mathrm{O}_{3}\right)$ and $\mathrm{PM}_{2.5}$ observations at 13 monitoring sites in $\mathrm{Xi}^{\prime}$ an and surrounding areas, released by the Ministry of Environmental Protection of China (China MEP), and daily filter measurement of $\mathrm{PM}_{2.5}, \mathrm{EC}$, and $\mathrm{OC}$ at 29 sites in GZB.

\subsubsection{Meteorological fields}

Figure 4 shows comparisons of the simulated and observed near-surface temperature, relative humidity, wind speed, and wind direction at the Jinghe meteorological station which is close to Xi' an (the yellow spot in Fig. 1c) from 23 to 25 April 2013. The simulated diurnal variations of temperature and relative humidity are in good agreement with the observations. The model also generally well reproduces the wind field compared with observations, except overestimation of the wind speed during the daytime of 23 April. No precipitation during the simulation period is observed or modeled.

\subsubsection{Hourly $\mathrm{O}_{3}$ and $\mathrm{PM}_{2.5}$ simulations in $\mathrm{Xi'}$ 'an and surrounding areas}

Figures 5 and 6 provide the spatial patterns of observed and simulated near-surface $\mathrm{O}_{3}$ and $\mathrm{PM}_{2.5}$ mass concentrations at 

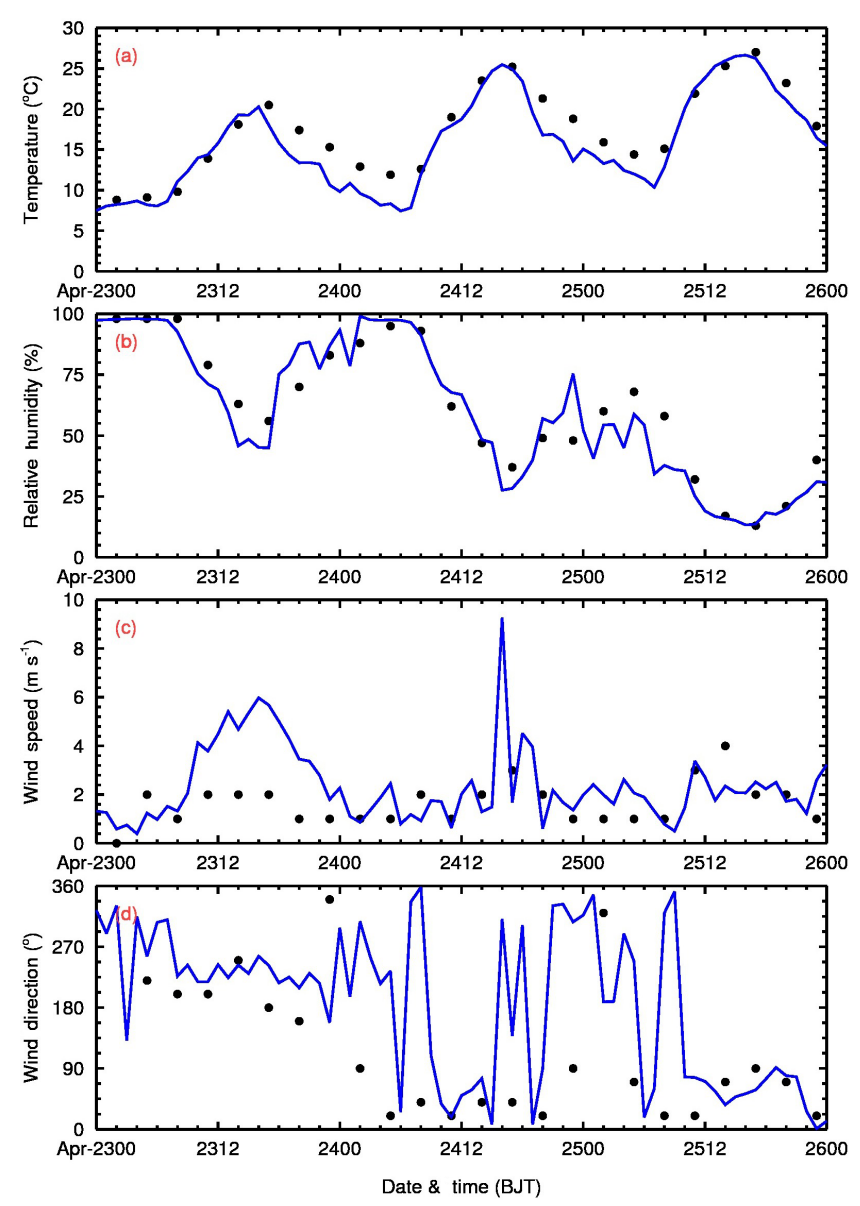

Figure 4. Temporal variations of simulated (blue line) and observed (black dots) meteorological fields including near-surface (a) temperature, (b) relative humidity, (c) wind speed, and (d) wind direction at the Jinghe meteorological station which is close to $\mathrm{Xi}$ 'an from 23 to 25 April 2013.

08:00 and 15:00 Beijing time (BJT) from 23 to 25 April 2013 in $\mathrm{Xi}$ ' an and surrounding areas, along with simulated wind fields. The calculated $\mathrm{O}_{3}$ and $\mathrm{PM}_{2.5}$ spatial distributions are generally consistent with the observations at the monitoring sites. At 08:00 BJT, the weak near-surface winds and the low planetary boundary layer (PBL, not shown) facilitate the accumulation of pollutants, causing observed and simulated high near-surface $\mathrm{PM}_{2.5}$ mass concentrations. The observed and calculated $\mathrm{PM}_{2.5}$ mass concentration frequently exceeds $150 \mu \mathrm{g} \mathrm{m}^{-3}$, causing heavy air pollution in Xi'an and surrounding areas. Weak solar insolation slows the photochemical activities and the low PBL is also favorable for buildup of emitted $\mathrm{NO}_{x}$, significantly lowering the $\mathrm{O}_{3}$ level at 08:00 BJT, and both the calculated and observed nearsurface $\mathrm{O}_{3}$ concentrations range from 20 to $30 \mu \mathrm{g} \mathrm{m}^{-3}$. At 15:00 BJT, with the development of PBL and enhancement of horizontal winds, the $\mathrm{PM}_{2.5}$ mass concentrations are decreased but still remain high level in Xi' an and surrounding areas on 23 and 24 April. The simulated strong divergence at 15:00 BJT on 25 April efficiently disperses the $\mathrm{PM}_{2.5}$ accumulated in the morning and remarkably improves the air quality in $\mathrm{Xi}$ ' an and surrounding areas, which is also shown by the observed $\mathrm{PM}_{2.5}$ concentrations. The observed and simulated $\mathrm{O}_{3}$ mass concentrations substantially increase to more than $80 \mu \mathrm{g} \mathrm{m}^{-3}$ at 15:00 BJT with the enhancement of photochemical activities.

Figure 7 presents the temporal variations of calculated and measured $\mathrm{O}_{3}$ and $\mathrm{PM}_{2.5}$ concentrations averaged over 13 monitoring sites in Xi' an and surrounding areas from 23 to 25 April 2013. The WRF-CHEM model generally replicates the observed $\mathrm{O}_{3}$ variations during the episode, i.e., the occurrence of peak $\mathrm{O}_{3}$ concentrations in the afternoon due to active photochemical processes and rapid falloff during nighttime caused by the $\mathrm{NO}_{x}$ titration. The MB and RMSE are 7.1 and $21.3 \mu \mathrm{g} \mathrm{m}^{-3}$, respectively, and the IOA is 0.89 . The model considerably overestimates the observed $\mathrm{O}_{3}$ concentration on 23 April, perhaps due to the high $\mathrm{O}_{3}$ background transport. However, on 25 April, the model notably underestimates the peak $\mathrm{O}_{3}$ concentration in the afternoon, which is caused by the simulated strong divergence in Xi' an and surrounding areas (Fig. 5). Figure 7 shows that the variations of observed $\mathrm{PM}_{2.5}$ are reasonably reproduced by the model, although overestimations and underestimations still exist. The MB and RMSE are 8.1 and $23.9 \mu \mathrm{g} \mathrm{m}^{-3}$, respectively, and the IOA is 0.86 . The observed and simulated $\mathrm{PM}_{2.5}$ mass concentrations both show that during the 3-day episode, the air quality with respect to $\mathrm{PM}_{2.5}$ in $\mathrm{Xi}^{\prime}$ an and surrounding areas gradually improves, with the $\mathrm{PM}_{2.5}$ concentration decreasing from about $160 \mu \mathrm{g} \mathrm{m}^{-3}$ in the morning on 23 April to about $50 \mu \mathrm{g} \mathrm{m}^{-3}$ in the afternoon on 25 April. The $\mathrm{PM}_{2.5}$ mass concentrations are generally elevated in the morning during the episode, probably due to the weak or calm horizontal winds, slow development of PBL, and the morning rush hour emissions. The $\mathrm{PM}_{2.5}$ levels fall in the afternoon, as a result of the enhanced dispersion in the horizontal and vertical directions. The deviations between the model results and observations might be caused by the rapid changes in anthropogenic emissions that are not reflected in the current emission inventories, or the uncertainties in the meteorological filed simulations (Bei et al., 2008, 2010, 2012).

\subsubsection{Daily $\mathrm{PM}_{2.5}$ and EC simulations in GZB}

Daily filter measurements of $\mathrm{PM}_{2.5}$ and EC mass concentrations at 29 sites in GZB (squares in Fig. 1) are used to further verify the WRF-CHEM model simulations. Figure 8 shows the scatter plots of calculated and measured daily $\mathrm{PM}_{2.5}$ and $\mathrm{EC}$ mass concentrations at 29 sites during the episode. The simulated daily $\mathrm{PM}_{2.5}$ mass concentrations are generally in agreement with the filter measurement over 29 sites. The $\mathrm{PM}_{2.5}$ concentration averaged over 29 sites during the episode is $79 \mu \mathrm{g} \mathrm{m}^{-3}$, close to the ob- 

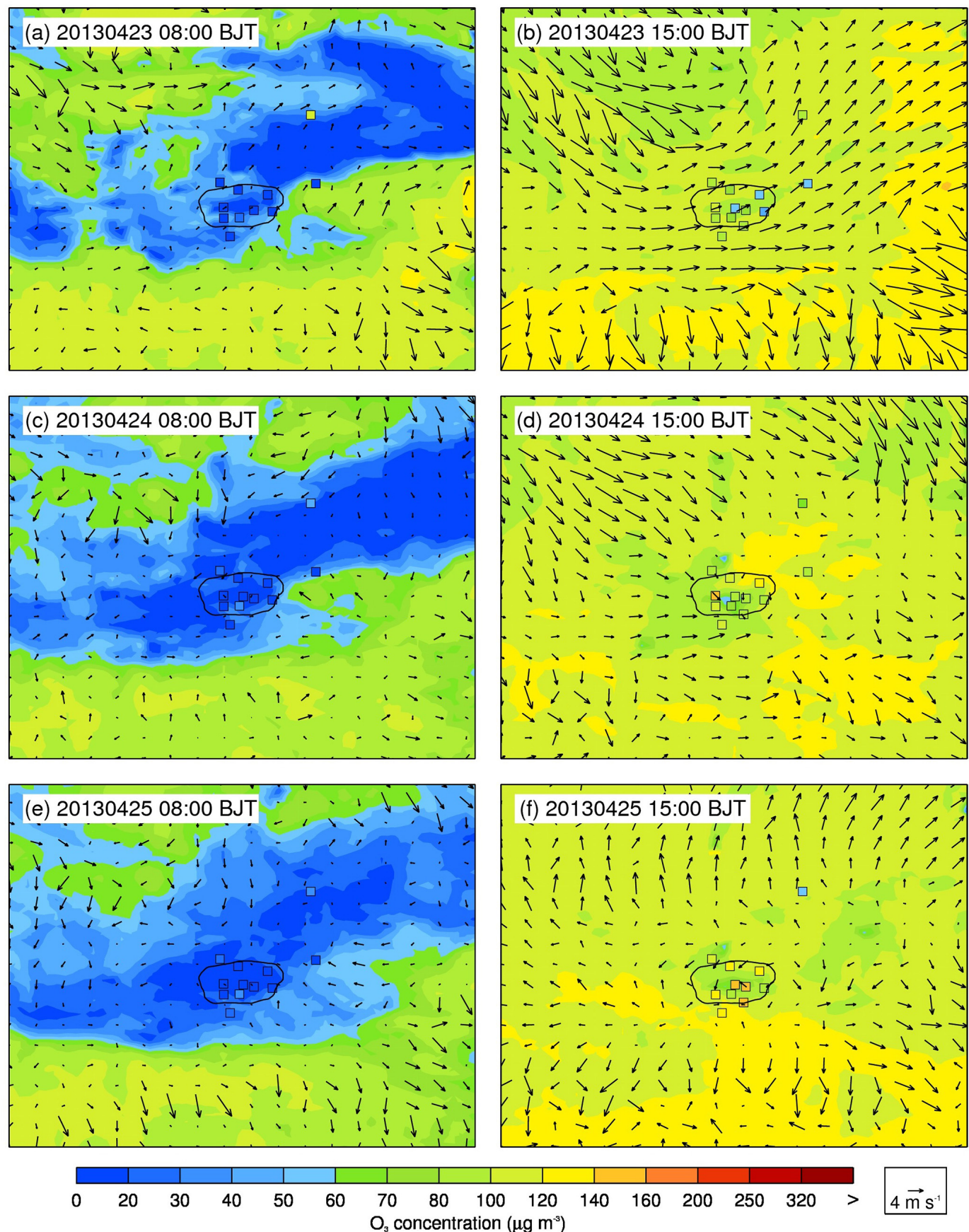

Figure 5. Spatial patterns of calculated (contours) and observed (squares) $\mathrm{O}_{3}$ concentrations at 08:00 and 15:00 BJT from 23 to 25 April 2013 along with wind fields (back arrows).

served $87 \mu \mathrm{g} \mathrm{m}^{-3}$. The MB and RMSE of $\mathrm{PM}_{2.5}$ mass concentrations are -7.4 and $10.3 \mu \mathrm{g} \mathrm{m}^{-3}$, showing a reasonable $\mathrm{PM}_{2.5}$ simulation in GZB. The WRF-CHEM model slightly overestimates the observed EC mass concentrations, with the MB of $0.2 \mu \mathrm{g} \mathrm{m}^{-3}$ and the RMSE of $0.6 \mu \mathrm{g} \mathrm{m}^{-3}$.

The calculated daily spatial patterns of $\mathrm{PM}_{2.5}$ and EC mass concentrations are displayed in Fig. 9 along with the measurements at the 29 sites. The simulated distributions of
$\mathrm{PM}_{2.5}$ and EC mass concentrations are consistent with the filter measurements. On 23 April, the eastern part of GZB is the most polluted area, with the daily $\mathrm{PM}_{2.5}$ mass concentrations exceeding $115 \mu \mathrm{g} \mathrm{m}^{-3}$. The daily $\mathrm{PM}_{2.5}$ mass concentrations are still high on 24 April, exceeding $75 \mu \mathrm{g} \mathrm{m}^{-3}$ over most of the area in GZB. The air quality in GZB is considerably improved on 25 April, and the daily $\mathrm{PM}_{2.5}$ mass concentrations are generally less than $75 \mu \mathrm{g} \mathrm{m}^{-3}$ in the north 

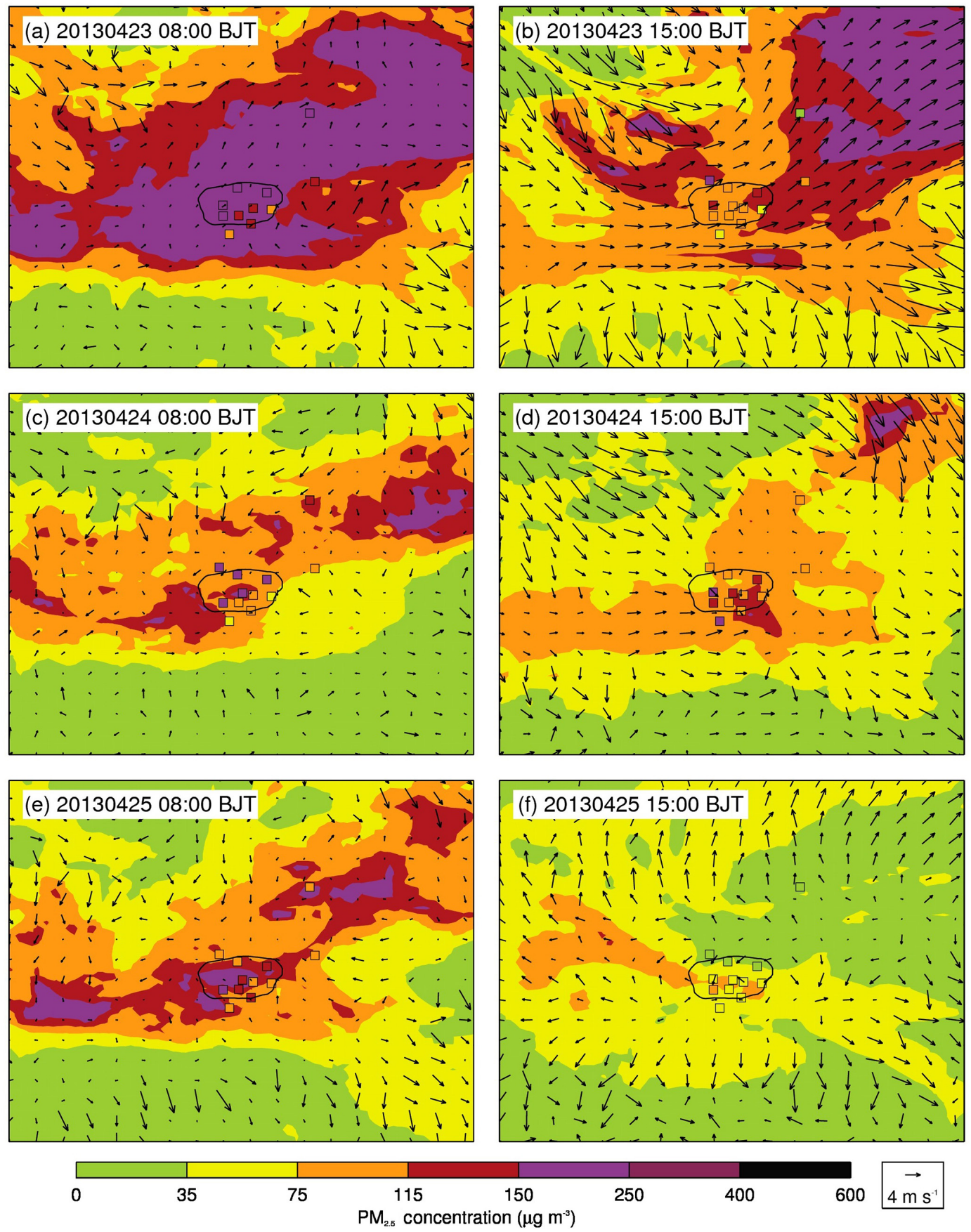

Figure 6. Spatial patterns of calculated (contours) and observed (squares) $\mathrm{PM}_{2.5}$ concentrations at 08:00 and 15:00 BJT from 23 to 25 April 2013 along with wind fields (back arrows).

part of GZB. The EC distributions do not exhibit remarkable variations from 23 to 25 April, indicating that the EC levels are primarily determined by direct emissions. In addition, although the daily $\mathrm{PM}_{2.5}$ mass concentrations decrease substantially from 23 to 25 April, the variations of EC mass concentrations are not so significant.
The WRF-CHEM model generally well reproduces $\mathrm{O}_{3}$ and $\mathrm{PM}_{2.5}$ concentrations in Xi' an and surrounding areas, and the daily $\mathrm{EC}$ and $\mathrm{PM}_{2.5}$ mass concentrations in GZB, indicating that meteorological fields are well simulated and the emissions used are also reasonable in the study. 

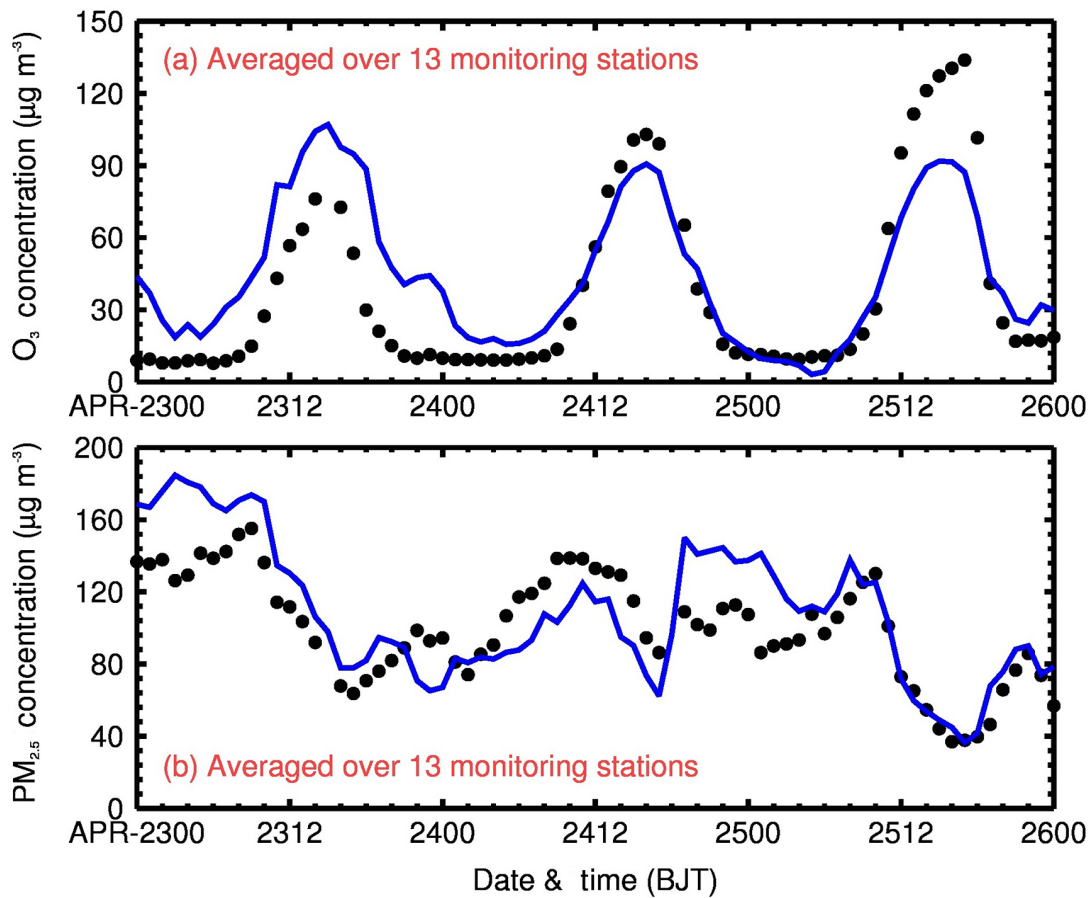

Figure 7. Temporal variations of simulated (blue line) and observed (black dots) (a) $\mathrm{O}_{3}$ and (b) $\mathrm{PM}_{2.5}$ concentrations averaged over 13 monitoring sites in Xi' an and surrounding areas from 23 to 25 April 2013.
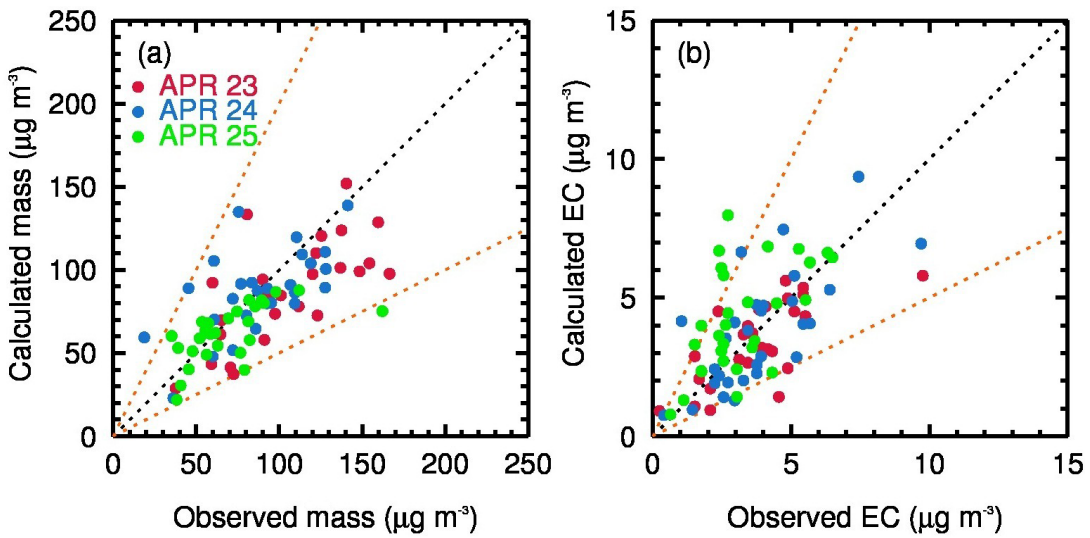

Figure 8. Comparisons between the predicted and measured daily (a) $\mathrm{PM}_{2.5}$ and (b) elemental carbon mass concentrations at 29 sites from 23 to 25 April 2013. The $1: 1,1: 2$, and $2: 1$ lines are plotted as dotted lines.

\subsection{Organic aerosols in GZB}

\subsubsection{OA simulations from the T2-SOA and NT-SOA modules}

Figure 10a shows that the scatterplot of the observed and simulated OA concentrations at 29 sites during the episode. The T2-SOA and NT-SOA modules exhibit different patterns in simulating OA in GZB, as shown in Fig. 10a. The T2SOA module overestimates the observed OA concentrations by about $33.6 \%$ averaged over the 29 sites, and the NT-SOA module underestimates the observation by about $4.3 \%$. Al- though the T2-SOA and NT-SOA modules both reproduce comparable OA levels against the measurements, the simulated OA components, i.e., POA and SOA, differ greatly between the two modules. Figure $10 \mathrm{~b}$ and $10 \mathrm{c}$ provide comparisons of the simulated POA and SOA concentrations from the T2-SOA and NT-SOA modules with the measurements, respectively. The T2-SOA module overestimates the measured POA by around $132.0 \%$, and only explains about $9.4 \%$ of the observed SOA concentration; the SOA underestimation of the T2-SOA module reaches a factor of 10 . The SOA simulations are comparable to Li et al. (2011b), in which the T2- 

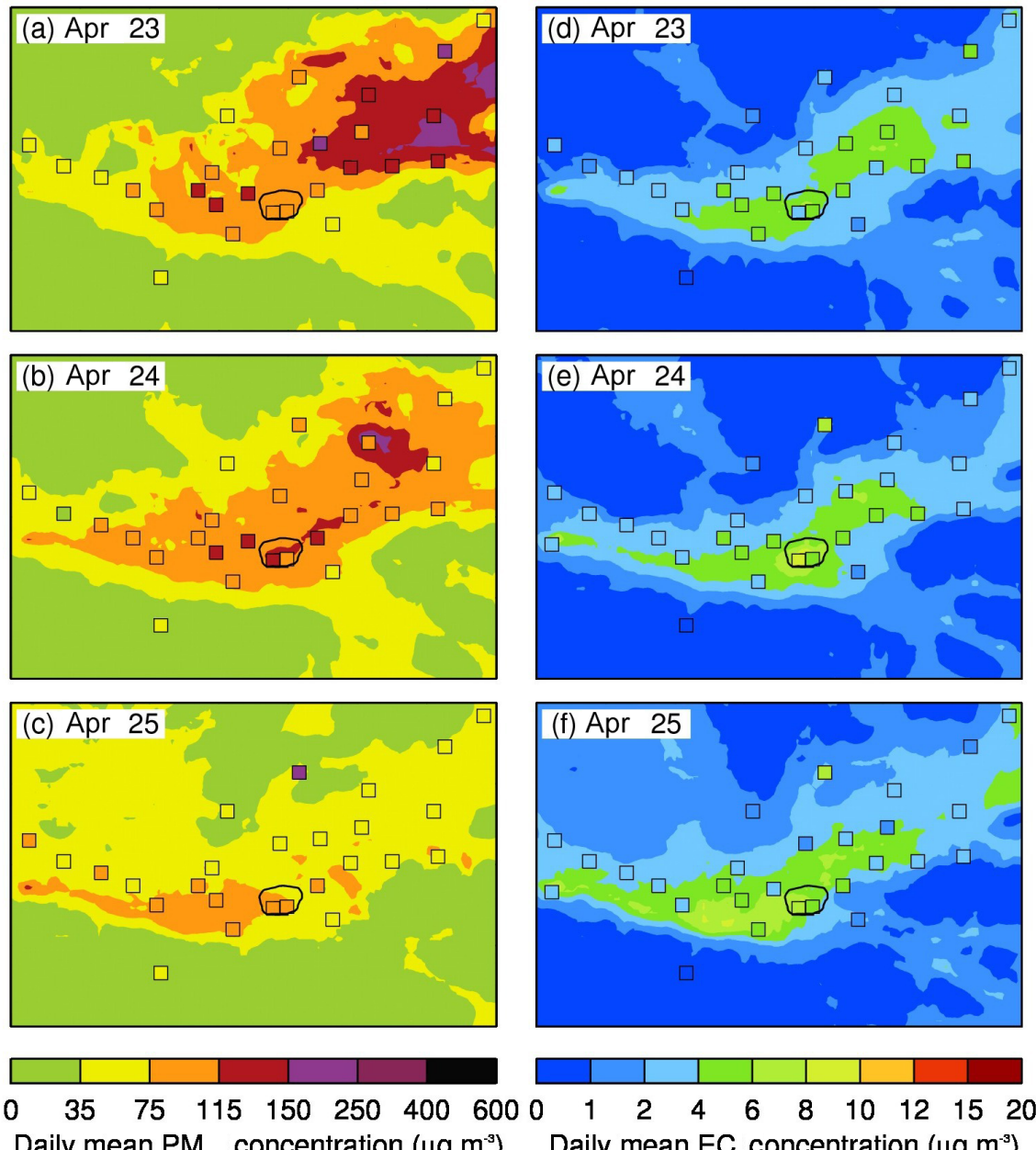

Daily mean $\mathrm{PM}_{25}$ concentration $\left(\mu \mathrm{g} \mathrm{m}^{-3}\right)$ Daily mean EC concentration $\left(\mu \mathrm{g} \mathrm{m}^{3}\right)$

Figure 9. Spatial distributions of calculated (contours) and observed (squares) daily $\mathrm{PM}_{2.5}$ (left column) and EC (right column) concentrations from 23 to 25 April 2013.
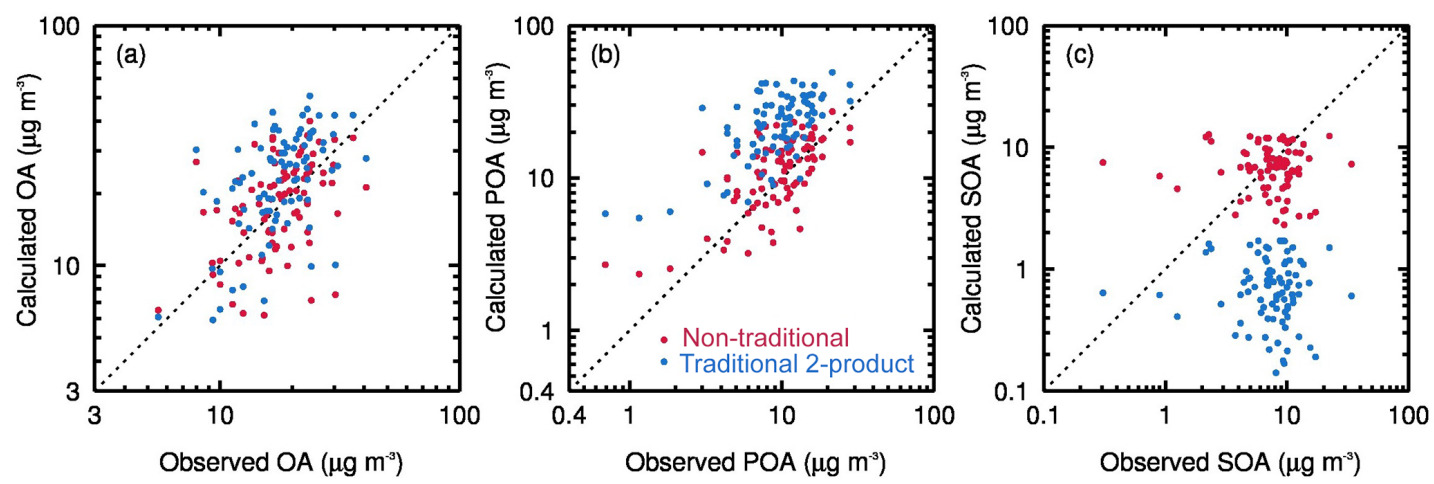

Figure 10. Scatter plots of the simulated (a) OA, (b) POA, and (c) SOA from the traditional (blue spots) and non-traditional (red spots) SOA modules against the observations at 29 sites from 23 to 25 April 2013.

SOA module fails to yield sufficient SOA concentrations to match the observations by a factor of 7. As a comparison, the NT-SOA module overestimates the observed POA by $17.5 \%$ and explains around $87.7 \%$ of the observed SOA concentra- tion, significantly improving the POA and SOA simulations. The NT-SOA module produces higher SOA than the T2SOA module because the total amount of material (POA plus semivolatile VOC plus intermediate VOC) included in the 


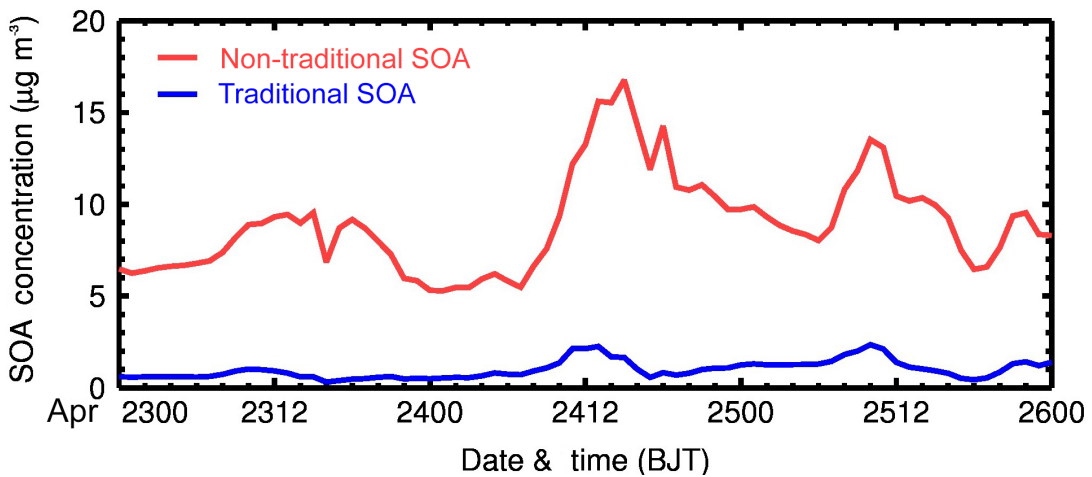

Figure 11. Temporal variations of the simulated SOA concentrations from the traditional (blue spots) and non-traditional (red spots) SOA modules in Xi' an and surrounding areas from 23 to 25 April 2013.

NT-SOA module is 7.5 times the particle-phase POA emissions, which is consistent with the conclusion obtained by $\mathrm{Li}$ et al. (2011). Besides, many studies have already shown that the VBS approach produces higher SOA than the traditional two-product SOA module (e.g., Hodzic et al., 2009; Tsimpidi et al., 2010).

The simulated POA / EC and SOA / EC ratios using NTSOA module are 3.23 and 2.23 , close to the measured 2.88 and 2.58, respectively. However, the simulations using T2SOA module are 6.54 and 0.22 , respectively, dramatically deviated from the measurements.

Figure 11 presents the temporal variations of simulated SOA mass concentrations in $\mathrm{Xi}$ ' an and surrounding areas from the T2-SOA and NT-SOA modules, respectively. Both the two modules produce peak SOA concentrations around noontime, but, apparently, the NT-SOA module yields much more SOA than the T2-SOA module because the NT-SOA module contains more precursors and production processes. The NT-SOA module remarkably improves the SOA yields during the entire episode to around $7.2 \mu \mathrm{g} \mathrm{m}^{-3}$ compared with the observed SOA of $8.2 \mu \mathrm{g} \mathrm{m}^{-3}$ averaged over the 29 sites, about a 10-fold increase compared with the simulations from the T2-SOA module $\left(0.77 \mu \mathrm{g} \mathrm{m}^{-3}\right)$.

\subsubsection{Urban, rural, and background POA and SOA}

The NT-SOA module significantly improves POA and SOA simulations, so we use the NT-SOA OA simulations for further comparisons and OA source apportionment. Figure 12 displays the spatial distributions of OA, POA, and SOA simulated by the NT-SOA module against the measurement in GZB. The simulated OA, POA, and SOA patterns are generally in agreement with the observations, but the model frequently underestimates the observations in the north part of GZB (Fig. 12). Both the simulation and the measurement show that the entire GZB is OA contaminated during the simulation episode ( $20 \mu \mathrm{g} \mathrm{m}^{-3}$ and above) (Fig. 12a-c). POA is primarily concentrated in the central part of GZB, directly linked to the source region (Fig. 12d-f). However, SOA is dispersed efficiently in the horizontal direction, showing the rapid aging process of OA. The simulations reveal a progressive increase of SOA concentrations in background areas, which is consistent with the measurements at the background site (red squares in Fig. 12g-i).

The comparisons of the calculated and measured SOA mass fractions in OA at urban, rural, and background sites using the NT-SOA module are displayed in Fig. 13. The average mass fractions over each type of site are colored red. The mass fractions of SOA in OA at urban and rural sites are very close (around $44-50 \%$ from the observations and around $40 \%$ from the simulation on average), suggesting a similar OA aging process in urban and rural areas of GZB. The SOA mass fraction at the background site is much higher, which well agrees with the observations (around $85 \%$ from the observations and around $70 \%$ from the simulation on average), indicating that the $\mathrm{OA}$ in background areas undergoes longtime aging processes.

The SOA formation pathways considered in the NTSOA module include (1) oxidation of anthropogenic VOCs (ASOA), (2) oxidation of biogenic VOCs (BSOA), (3) oxidation and partitioning of POA treated as semivolatile (PSOA), and (4) irreversible uptake of glyoxal and methylglyoxal on aerosol surfaces (GSOA). The SOA mass fractions in OA increase from $32.5-37.3 \%$ at urban sites to $36.3-44.1 \%$ at rural sites, and sharply to $58.6-75.7 \%$ at the background site (Table 4). PSOA dominates SOA mass concentrations at all sites, and its contribution to SOA increases from 77.9-79.5\% at urban sites to $86.9-89.4 \%$ at the background site, showing the continuous aging process of OA (Fig. 14). The SOA contribution from ASOA and GSOA decreases from urban sites to the background site, showing the abatement of direct anthropogenic impacts. At urban sites, ASOA, BSOA, and GSOA contribute comparably to the SOA mass concentration. At the background site, the SOA contribution from ASOA and GSOA is very low, less than $4 \%$. The GSOA constitutes about $5-10 \%$ of SOA mass in the afternoon at urban 

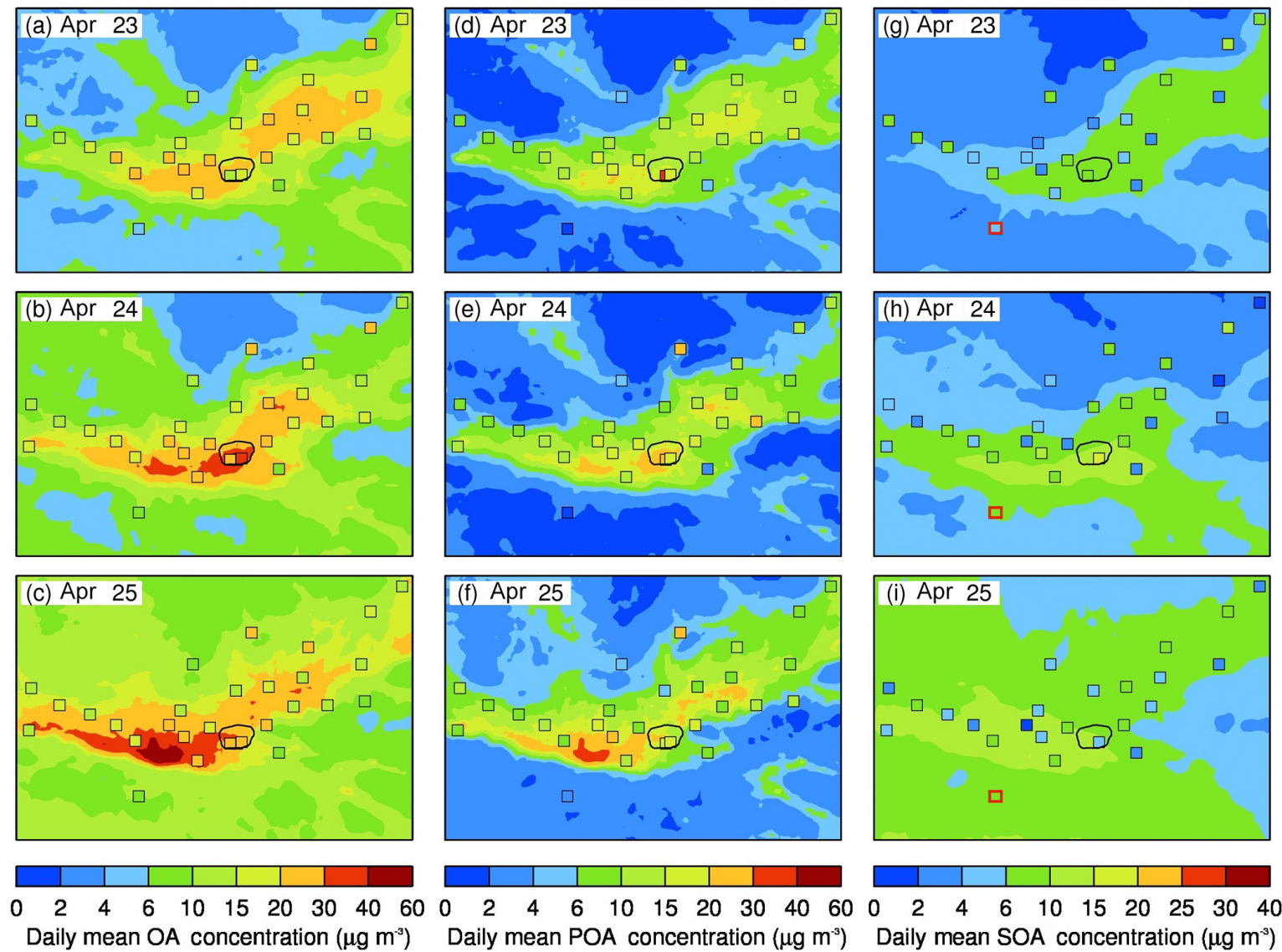

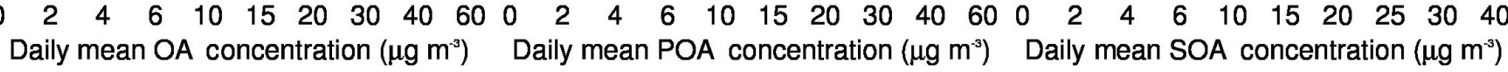

Figure 12. Spatial distributions of the NT-SOA module calculated (contours) and filter-observed (squares) daily OA (left column), POA (middle column), and SOA (right column) mass concentrations from 23 to 25 April 2013. Red squares in panels (g-i) show the location of the background site.

Table 4. Simulated mass fractions of SOA in the total OA, and the SOA contribution from various formation pathways averaged over the simulation period at urban, rural, and background sites.

\begin{tabular}{llrrrrr}
\hline Duration & Site type & SOA mass fraction & \multicolumn{4}{c}{ Mass fraction in SOA (\%) } \\
\cline { 4 - 7 } & & in OA (\%) & PSOA $^{\mathrm{a}}$ & ASOA $^{\mathrm{b}}$ & BSOA $^{\mathrm{c}}$ & GSOA $^{\mathrm{d}}$ \\
\hline \multirow{2}{*}{23 April } & Urban & 32.5 & 77.9 & 5.8 & 5.6 & 10.6 \\
& Rural & 36.3 & 80.3 & 5.2 & 5.1 & 9.4 \\
& Background & 58.6 & 86.9 & 4.0 & 5.4 & 3.7 \\
\hline \multirow{2}{*}{24 April } & Urban & 34.8 & 80.5 & 6.0 & 8.5 & 5.0 \\
& Rural & 39.9 & 84.4 & 4.0 & 8.5 & 3.1 \\
& Background & 74.4 & 89.4 & 3.2 & 5.8 & 1.6 \\
\hline \multirow{2}{*}{25 April } & Urban & 37.3 & 79.5 & 6.2 & 9.9 & 4.4 \\
& Rural & 44.1 & 80.7 & 5.3 & 10.3 & 3.7 \\
& Background & 75.7 & 89.2 & 2.4 & 6.8 & 1.6 \\
\hline
\end{tabular}

${ }^{a}$ SOA from oxidation and partitioning of POA treated as semivolatile. ${ }^{b}$ SOA from oxidation of anthropogenic VOCs. ${ }^{\mathrm{c}}$ SOA from oxidation of biogenic VOCs. ${ }^{\mathrm{d}}$ SOA from irreversible uptake of glyoxal and methylglyoxal on aerosol surfaces. 


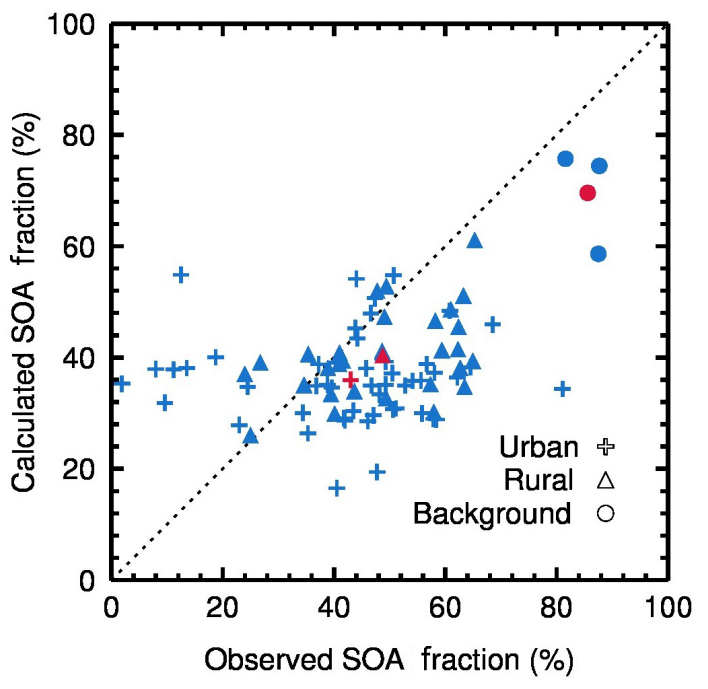

Figure 13. Comparisons between the NT-SOA module predicted and filter-measured daily SOA mass fraction in OA at urban, rural, and background sites during the simulation episode.

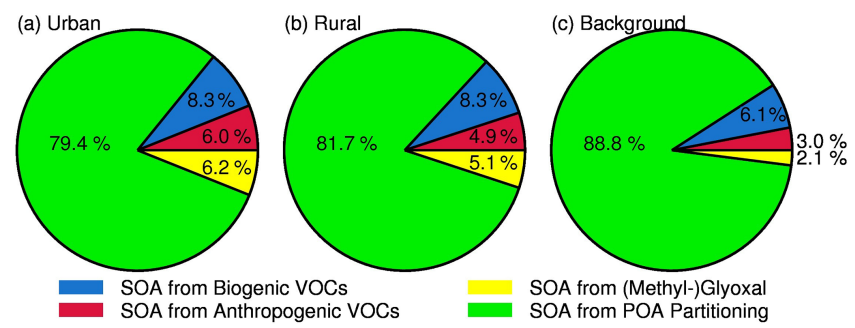

Figure 14. NT-SOA module simulated contributions of different formation pathways to SOA levels averaged over the simulation episode at (a) urban, (b) rural, and (c) background sites.

sites, close to the $9.6 \%$ contribution of the observed SOA mass in urban area of Mexico City (Li et al., 2011b).

\subsubsection{Contributions of anthropogenic emissions to $\mathrm{OA}$}

Sensitivity studies are conducted to estimate the contributions from anthropogenic emissions including industry, residential, and transportation sources to the OA mass concentrations during the episode. The factor separation approach (FSA) proposed by Stein and Alpert (1993) is utilized to decompose the contribution from an individual source. The simulation with all anthropogenic emissions is taken as the base case (referred to as BAS case) to compare with the sensitivity studies. Four sensitivity studies are performed, including (1) ANT case without all anthropogenic emissions, (2) RES case without the residential emission, (3) IND case without the industry emission, and (4) TRA case without the transportation emission in simulations. According to the FSA approach, the OA contribution from an individual source, i.e., residential emissions, can be calculated as OA(BAS $)$ - OA(RES).
Table 5 presents OA concentrations and contributions and OA contributions to $\mathrm{PM}_{2.5}$ from anthropogenic emissions averaged over the simulation period at urban, rural, and background sites. During the simulation episode, anthropogenic emissions play a predominant role in the OA formation at the urban and rural sites, with the OA contribution of $82.4 \%$ $\left(18.2 \mu \mathrm{g} \mathrm{m}^{-3}\right)$ and $77.3 \%\left(12.8 \mu \mathrm{g} \mathrm{m}^{-3}\right)$, respectively. At the background site, the OA contribution from anthropogenic emissions is close to $60 \%\left(4.7 \mu \mathrm{g} \mathrm{m}^{-3}\right)$, showing that the background area is still substantially influenced by human activities despite the far distance from the urban area. Residential emissions are the most important anthropogenic OA source at the urban and rural sites in the present study, with the OA contribution close to $50 \%$, indicating that reducing residential emission is an efficient approach for OA mitigation in GZB. The OA contribution from the transportation source is $25.0 \%$ at the urban sites, exceeding $20.3 \%$ at the rural sites and $19.8 \%$ at the background sites. The industry emission is not an important OA source in GZB, with the contribution less than $6.1 \%$. It is worth to note that the OA contributions from residential, transportation, and industry emissions are comparable at the urban and rural sites, which probably is due to the rapid transport and transformation process between urban and rural areas. In addition, the urbanization and industrialization in GZB may also rapidly diminish the OA source difference between the rural and urban areas.

\section{Summary and conclusions}

A 3-day episode from 23 to 25 April 2013 is simulated in the Guanzhong Basin, China using the WRF-CHEM model to examine identify OA sources and SOA formation. We use two SOA approaches to simulate OA: a traditional twoproduct SOA module and a non-traditional SOA module including VBS modeling method and the SOA contribution from dicarbonyl compounds. Meteorological observations during the simulation period are assimilated using the FDDA method in WRF-CHEM simulations. Model results are compared with the meteorological observations, hourly $\mathrm{O}_{3}$ and $\mathrm{PM}_{2.5}$ measurements in Xi' an and surrounding areas, and the $\mathrm{PM}_{2.5}$ carbonaceous components from the OC and EC field filter measurements in GZB.

The WRF-CHEM model generally well simulates the spatial distributions and temporal variations of near-surface $\mathrm{O}_{3}$ and $\mathrm{PM}_{2.5}$, but biases still exist due to the uncertainties of meteorological fields and emission inventories. The model performs reasonably well in reproducing the distribution of the filter-measured daily $\mathrm{PM}_{2.5}$ and $\mathrm{EC}$ in GZB, but underestimates the observed $\mathrm{PM}_{2.5}$ mass concentration by $7.4 \mu \mathrm{g} \mathrm{m}^{-3}$ on average.

The OC / EC ratio approach is used to evaluate OA, POA, and SOA concentrations from the filter-measured $\mathrm{OC}$ and EC concentrations. The traditional and non-traditional SOA modules both yield reasonable OA simulations compared 
Table 5. OA concentrations and contributions and OA contributions to $\mathrm{PM}_{2.5}$ from anthropogenic emissions averaged over the simulation period at urban, rural, and background sites.

\begin{tabular}{|c|c|c|c|}
\hline & $\begin{array}{r}\text { OA concentration } \\
\left(\mu \mathrm{g} \mathrm{m}^{-3}\right)\end{array}$ & $\begin{array}{r}\text { OA contribution } \\
(\%)\end{array}$ & $\begin{array}{l}\text { OA contribution } \\
\text { to } \mathrm{PM}_{2.5}(\%)\end{array}$ \\
\hline \multicolumn{4}{|l|}{ Urban } \\
\hline Ant. $^{\mathrm{a}}$ & 18.2 & 82.4 & 19.2 \\
\hline Res. $^{\text {b }}$ & 10.4 & 47.2 & 11.0 \\
\hline $\operatorname{Tra}^{\mathrm{c}}$ & 5.5 & 25.0 & 5.8 \\
\hline Ind. $^{\mathrm{d}}$ & 1.3 & 6.1 & 1.4 \\
\hline \multicolumn{4}{|l|}{ Rural } \\
\hline Ant. $^{\mathrm{a}}$ & 12.8 & 77.3 & 15.8 \\
\hline Res. $^{\text {b }}$ & 7.9 & 47.8 & 9.8 \\
\hline Tra. $^{c}$ & 3.4 & 20.3 & 4.1 \\
\hline Ind. $^{\mathrm{d}}$ & 0.4 & 2.6 & 0.5 \\
\hline \multicolumn{4}{|c|}{ Background } \\
\hline Ant. $^{\mathrm{a}}$ & 4.7 & 58.6 & 19.0 \\
\hline Res. $^{\text {b }}$ & 2.4 & 30.2 & 9.8 \\
\hline Tra. $^{\mathrm{c}}$ & 1.6 & 19.8 & 6.4 \\
\hline Ind. $^{\mathrm{d}}$ & 0.0 & 0.0 & 0.0 \\
\hline
\end{tabular}

with measurements, but perform differently in simulating POA and SOA. The traditional module overestimates the measured POA concentration by around $132.0 \%$ but underestimates the observed SOA concentration by a factor of 10. The non-traditional module overestimates the observed POA concentration by $17.5 \%$ and explains around $87.7 \%$ of the observed SOA concentration, significantly improving the POA and SOA simulations. Although the model can produce similar $\mathrm{PM}_{2.5}$ simulations when using the traditional and non-traditional SOA modules, the results might be misleading when the traditional SOA module is used to develop the $\mathrm{PM}_{2.5}$ mitigation strategy.

Simulations from the non-traditional SOA module show that oxidation and partitioning of POA which is treated as semivolatile in the model dominate the SOA concentration in GZB, with the SOA contribution exceeding $75 \%$ and also gradually increasing from urban sites to the background site. During the simulated period, the oxidation of anthropogenic and biogenic VOCs and the irreversible uptake of dicarbonyl compounds do not constitute an important SOA formation pathway in GZB, with the SOA contributions less than $10 \%$ generally. Anthropogenic emissions are the dominant OA source at urban and rural sites, contributing over $70 \%$ of OA concentrations. Residential emissions are the most important anthropogenic OA sources, constituting about $50 \%$ of OA concentrations at urban and rural sites and $30.2 \%$ at the background site. Transportation emissions make up $25.0 \%$ of the OA concentrations at urban sites and decrease to $19.8 \%$ at the background site. The OA contribution from industry emissions is less than $6.1 \%$ in GZB.

Although the WRF-CHEM model predicts the patterns and variations of observed $\mathrm{O}_{3}, \mathrm{PM}_{2.5}$, and aerosol components reasonably well, biases still exist. It is worth to note that many factors contribute to the OA and SOA simulation uncertainties, such as measurements, meteorology, emissions, SOA formation mechanisms and treatments, etc.; even the right modeling results might be caused by wrong reasons (e.g., right concentrations but wrong $\mathrm{O} / \mathrm{C}$ ratios). To better simulate the SOA formation, the SOA mechanisms and treatments need further revising and improving to reasonably represent OA formation and development in the atmosphere, such as including the oxidation degree, rather than only nine surrogates categorized by saturation concentrations. Additionally, reducing uncertainties from meteorological field simulations and emissions is also imperative for improving the SOA simulation. In addition to OA, other aerosol species, such as sulfate, nitrate, ammonium, and mineral dust, also play important roles in the haze formation. Further source appointment of those aerosol species is needed to support the design of mitigation strategies. It should be noted that this simulation is conducted during 3 days in spring 2013, so it might be only partially representative of the springtime $\mathrm{PM}_{2.5}$ and $\mathrm{OC}$ pollution. Nevertheless, considering that the $\mathrm{PM}_{2.5}$ and $\mathrm{OC}$ concentrations during the study period are similar to those in the past 5 years, the model result is still important and provides a reference for springtime OA formation.

\section{Data availability}

The real-time $\mathrm{O}_{3}$ and $\mathrm{PM}_{2.5}$ are accessible for the public on the website http://106.37.208.233:20035/ (China MEP, 2013a). One can also access the historic profile of observed ambient pollutants through visiting http://www.aqistudy.cn/ (China MEP, 2013b).

Acknowledgements. This work was supported by the National Natural Science Foundation of China (no. 41275153) and supported by the Strategic Priority Research Program of the Chinese Academy of Sciences, grant no. XDB05060500. Guohui Li is also supported by the Hundred Talents Program of the Chinese Academy of Sciences. Naifang Bei is supported by the National Natural Science Foundation of China (no. 41275101).

Edited by: L. Zhang

Reviewed by: three anonymous referees 


\section{References}

Aiken, A. C., DeCarlo, P. F., Kroll, J. H., Worsnop, D. R., Huffman, J. A., Docherty, K. S., Ulbrich, I. M., Mohr, C., Kimmel, J. R., Sueper, D., Sun, Y., Zhang, Q., Trimborn, A., Northway, M., Ziemann, P. J., Canagaratna, M. R., Onasch, T. B., Alfarra, M. R., Prévôt, A. S. H., Dommen, J., Duplissy, J., Metzger, A., Baltensperger, U., and Jimenez, J. L.: O / C and OM / OC Ratios of Primary, Secondary, and Ambient Organic Aerosols with HighResolution Time-of-Flight Aerosol Mass Spectrometry, Environ. Sci. Technol., 42, 4478-4485, doi:10.1021/es703009q, 2008.

Bei, N., de Foy, B., Lei, W., Zavala, M., and Molina, L. T.: Using 3DVAR data assimilation system to improve ozone simulations in the Mexico City basin, Atmos. Chem. Phys., 8, 7353-7366, doi:10.5194/acp-8-7353-2008, 2008.

Bei, N., Lei, W., Zavala, M., and Molina, L. T.: Ozone predictabilities due to meteorological uncertainties in the Mexico City basin using ensemble forecasts, Atmos. Chem. Phys., 10, 6295-6309, doi:10.5194/acp-10-6295-2010, 2010.

Bei, N., Li, G., and Molina, L. T.: Uncertainties in SOA simulations due to meteorological uncertainties in Mexico City during MILAGRO-2006 field campaign, Atmos. Chem. Phys., 12, 11295-11308, doi:10.5194/acp-12-11295-2012, 2012.

Binkowski, F. S. and Roselle, S. J.: Models-3 Community Multiscale Air Quality (CMAQ) model aerosol component 1. Model description, J. Geophys. Res., 108, 4183, doi:10.1029/2001JD001409, 2003.

Cao, J. J., Lee, S. C., Ho, K. F., Zhang, X. Y., and Zou, S. C.: Characteristics of carbonaceous aerosol in Pearl River Delta Region, China during 2001 winter period, Atmos. Environ., 37, 14511460, doi:10.1016/s1352-2310(02)01002-6, 2003.

Cao, J. J., Lee, S. C., Ho, K. F., Zou, S. C., Fung, K., Li, Y., Watson, J. G., and Chow, J. C.: Spatial and seasonal variations of atmospheric organic carbon and elemental carbon in Pearl River Delta Region, China, Atmos. Environ., 38, 4447-4456, doi:10.1016/j.atmosenv.2004.05.016, 2004.

Cao, J. J., Wu, F., Chow, J. C., Lee, S. C., Li, Y., Chen, S. W., An, Z. S., Fung, K. K., Watson, J. G., Zhu, C. S., and Liu, S. X.: Characterization and source apportionment of atmospheric organic and elemental carbon during fall and winter of 2003 in Xi'an, China, Atmos. Chem. Phys., 5, 3127-3137, doi:10.5194/acp-53127-2005, 2005.

Cao, J. J., Lee, S. C., Chow, J. C., Watson, J. G., Ho, K. F., Zhang, R. J., Jin, Z. D., Shen, Z. X., Chen, G. C., Kang, Y. M., Zou, S. C., Zhang, L. Z., Qi, S. H., Dai, M. H., Cheng, Y., and Hu, K.: Spatial and seasonal distributions of carbonaceous aerosols over China, J. Geophys. Res., 112, D22S11, doi:10.1029/2006JD008205, 2007.

Cao, J. J., Xu, H., Xu, Q., Chen, B., and Kan, H.: Fine particulate matter constituents and cardiopulmonary mortality in a heavily polluted Chinese city, Environ. Health Persp., 120, 373-378, doi:10.1289/ehp.1103671, 2012a.

Cao, J.-J., Wang, Q.-Y., Chow, J. C., Watson, J. G., Tie, X.-X., Shen, Z.-X., Wang, P., and An, Z.-S.: Impacts of aerosol compositions on visibility impairment in Xi'an, China, Atmos. Environ., 59, 559-566, doi:10.1016/j.atmosenv.2012.05.036, 2012 b.

Cao, J.-J., Zhu, C.-S., Tie, X.-X., Geng, F.-H., Xu, H.-M., Ho, S. S. H., Wang, G.-H., Han, Y.-M., and Ho, K.-F.: Characteristics and sources of carbonaceous aerosols from Shanghai, China, Atmos. Chem. Phys., 13, 803-817, doi:10.5194/acp-13-803-2013, 2013.
Donahue, N. M., Robinson, A. L., Stanier, C. O., and Pandis, S. N.: Coupled Partitioning, Dilution, and Chemical Aging of Semivolatile Organics, Environ. Sci. Technol., 40, 2635-2643, doi:10.1021/es052297c, 2006.

Dudhia, J.: Numerical study of convection observed during the winter monsoon experiment using a mesoscale two-dimensional model, J. Atmos. Sci., 46, 3077-3107, doi:10.1175/15200469(1989)046<3077:NSOCOD>2.0.CO;2, 1989.

Dudhia, J.: A multi-layer soil temperature model for MM5, the 6th Annual MM5 Users Workshop, 22-24 July 1996, Boulder, CO, USA, 1996.

Dzepina, K., Volkamer, R. M., Madronich, S., Tulet, P., Ulbrich, I. M., Zhang, Q., Cappa, C. D., Ziemann, P. J., and Jimenez, J. L.: Evaluation of recently-proposed secondary organic aerosol models for a case study in Mexico City, Atmos. Chem. Phys., 9, 5681-5709, doi:10.5194/acp-9-5681-2009, 2009.

Greenwald, R., Bergin, M. H., Xu, J., and Cohan, D.: The influence of aerosols on crop production: A study using the CERES crop model, Agr. Syst., 89, 390-413, doi:10.1016/j.agsy.2005.10.004, 2006.

Grell, G. A., Peckham, S. E., Schmitz, R., McKeen, S. A., Frost, G., Skamarock, W. C., and Eder, B.: Fully coupled "online" chemistry within the WRF model, Atmos. Environ., 39, 6957-6975, doi:10.1016/j.atmosenv.2005.04.027, 2005.

Guenther, A., Karl, T., Harley, P., Wiedinmyer, C., Palmer, P. I., and Geron, C.: Estimates of global terrestrial isoprene emissions using MEGAN (Model of Emissions of Gases and Aerosols from Nature), Atmos. Chem. Phys., 6, 3181-3210, doi:10.5194/acp-63181-2006, 2006.

Guinot, B., Cachier, H., Sciare, J., Tong, Y., Xin, W., and Jianhua, Y.: Beijing aerosol: Atmospheric interactions and new trends, J. Geophys. Res., 112, D14314, doi:10.1029/2006JD008195, 2007.

He, H., Tie, X., Zhang, Q., Liu, X., Gao, Q., Li, X., and Gao, Y.: Analysis of the causes of heavy aerosol pollution in Beijing, China: A case study with the WRF-Chem model, Particuology, 20, 32-40, doi:10.1016/j.partic.2014.06.004, 2015.

He, K., Yang, F., Ma, Y., Zhang, Q., Yao, X., Chan, C. K., Cadle, S., Chan, T., and Mulawa, P.: The characteristics of $\mathrm{PM}_{2.5}$ in Beijing, China, Atmos. Environ., 35, 4959-4970, doi:10.1016/S1352-2310(01)00301-6, 2001.

Hodzic, A., Jimenez, J. L., Madronich, S., Aiken, A. C., Bessagnet, B., Curci, G., Fast, J., Lamarque, J.-F., Onasch, T. B., Roux, G., Schauer, J. J., Stone, E. A., and Ulbrich, I. M.: Modeling organic aerosols during MILAGRO: importance of biogenic secondary organic aerosols, Atmos. Chem. Phys., 9, 6949-6981, doi:10.5194/acp-9-6949-2009, 2009.

Hong, S. Y. and Lim, J.: The WRF single-moment 6-class microphysics scheme (WSM6), Asia-Pac. J. Atmos. Sci., 42, 129-151, 2006.

Hong, S. Y., Noh, Y., and Dudhia, J.: A new vertical diffusion package with an explicit treatment of entrainment processes, Mon. Weather Rev., 134, 2318-2341, doi:10.1175/mwr3199.1, 2006.

Horowitz, L. W., Walters, S., and Mauzerall, D. L.: A global simulation of tropospheric ozone and related tracers: Description and evaluation of MOZART, version 2, J. Geophys. Res., 108, 4784, doi:10.1029/2002jd002853, 2003.

Huang, R.-J., Zhang, Y., Bozzetti, C., Ho, K.-F., Cao, J.-J., Han, Y., Daellenbach, K. R., Slowik, J. G., Platt, S. M., Canonaco, F., Zotter, P., Wolf, R., Pieber, S. M., Bruns, E. A., Crippa, M., Ciarelli, 
G., Piazzalunga, A., Schwikowski, M., Abbaszade, G., SchnelleKreis, J., Zimmermann, R., An, Z., Szidat, S., Baltensperger, U., El Haddad, I., and Prévôt, A. S. H.: High secondary aerosol contribution to particulate pollution during haze events in China, Nature, 514, 218-222, doi:10.1038/nature13774, 2014.

Kanakidou, M., Seinfeld, J. H., Pandis, S. N., Barnes, I., Dentener, F. J., Facchini, M. C., Van Dingenen, R., Ervens, B., Nenes, A., Nielsen, C. J., Swietlicki, E., Putaud, J. P., Balkanski, Y., Fuzzi, S., Horth, J., Moortgat, G. K., Winterhalter, R., Myhre, C. E. L., Tsigaridis, K., Vignati, E., Stephanou, E. G., and Wilson, J.: Organic aerosol and global climate modelling: a review, Atmos. Chem. Phys., 5, 1053-1123, doi:10.5194/acp-5-1053-2005, 2005.

Lane, T. E., Donahue, N. M., and Pandis, S. N.: Simulating secondary organic aerosol formation using the volatility basis-set approach in a chemical transport model, Atmos. Environ., 42, 7439-7451, doi:10.1016/j.atmosenv.2008.06.026, 2008.

Li, G., Zhang, R., Fan, J., and Tie, X.: Impacts of black carbon aerosol on photolysis and ozone, J. Geophys. Res., 110, D23206, doi:10.1029/2005JD005898, 2005.

Li, G., Lei, W., Zavala, M., Volkamer, R., Dusanter, S., Stevens, P., and Molina, L. T.: Impacts of HONO sources on the photochemistry in Mexico City during the MCMA-2006/MILAGO Campaign, Atmos. Chem. Phys., 10, 6551-6567, doi:10.5194/acp-106551-2010, 2010.

Li, G., Bei, N., Tie, X., and Molina, L. T.: Aerosol effects on the photochemistry in Mexico City during MCMA2006/MILAGRO campaign, Atmos. Chem. Phys., 11, 51695182, doi:10.5194/acp-11-5169-2011, 2011a.

Li, G., Zavala, M., Lei, W., Tsimpidi, A. P., Karydis, V. A., Pandis, S. N., Canagaratna, M. R., and Molina, L. T.: Simulations of organic aerosol concentrations in Mexico City using the WRFCHEM model during the MCMA-2006/MILAGRO campaign, Atmos. Chem. Phys., 11, 3789-3809, doi:10.5194/acp-11-37892011, 2011b.

Li, G., Lei, W., Bei, N., and Molina, L. T.: Contribution of garbage burning to chloride and $\mathrm{PM}_{2.5}$ in Mexico City, Atmos. Chem. Phys., 12, 8751-8761, doi:10.5194/acp-12-8751-2012, 2012.

Lipsky, E. M. and Robinson, A. L.: Effects of Dilution on Fine Particle Mass and Partitioning of Semivolatile Organics in Diesel Exhaust and Wood Smoke, Environ. Sci. Technol., 40, 155-162, doi:10.1021/es050319p, 2006.

Ministry of Environmental Protection, China (China MEP): Air Quality Observation Real-time Release Platform of MEP Data Center, available at: http://106.37.208.233:20035/ (last access: 8 August 2016), 2013a.

Ministry of Environmental Protection, China (China MEP): Online Monitoring and Analysis Platform of China Air Quality, available at: http://www.aqistudy.cn/ (last access: 8 August 2016), $2013 b$.

Mlawer, E. J., Taubman, S. J., Brown, P. D., Iacono, M. J., and Clough, S. A.: Radiative transfer for inhomogeneous atmospheres: RRTM, a validated correlated-k model for the longwave, J. Geophys. Res., 102, 16663-16682, doi:10.1029/97JD00237, 1997.

Murphy, B. N. and Pandis, S. N.: Simulating the Formation of Semivolatile Primary and Secondary Organic Aerosol in a Regional Chemical Transport Model, Environ. Sci. Technol., 43, 4722-4728, doi:10.1021/es803168a, 2009.
Nenes, A., Pilinis, C., and Pandis, S. N.: ISORROPIA: A New Thermodynamic Equilibrium Model for Multiphase Multicomponent Inorganic Aerosols, Aquat. Geochem., 4, 123-152, 1998.

Odum, J. R., Hoffmann, T., and Bowman, F.: Gas/particle partitioning and secondary organic aerosol yields, Environ. Sci. Technol., 30, 2580-2585, doi:10.1021/es950943, 1996.

Pankow, J. F.: An absorption model of gas/particle partitioning of organic compounds in the atmosphere, Atmos. Environ., 28, 185-188, doi:10.1016/1352-2310(94)90093-0, 1994.

Robinson, A. L., Donahue, N. M., Shrivastava, M. K., Weitkamp, E. A., Sage, A. M., Grieshop, A. P., Lane, T. E., Pierce, J. R., and Pandis, S. N.: Rethinking organic aerosols: semivolatile emissions and photochemical aging, Science, 315, 1259-1262, doi:10.1126/science.1133061, 2007.

Schell, B., Ackermann, I. J., Hass, H., Binkowski, F. S., and Ebel, A.: Modeling the formation of secondary organic aerosol within a comprehensive air quality model system, J. Geophys. Res., 106, 28275-28293, doi:10.1029/2001jd000384, 2001.

Seinfeld, J. H. and Pandis, S. N.: Atmospheric Chemistry and Physics - From Air Pollution to Climate Change, 2nd ed., John Wiley \& Sons, New Jersey, USA, 2006.

Shen, Z., Arimoto, R., Cao, J., Zhang, R., and Li, X.: Seasonal Variations and Evidence for the Effectiveness of Pollution Controls on Water-Soluble Inorganic Species in Total Suspended Particulates and Fine Particulate Matter from Xi' an, China, J. Air Waste Manage., 58, 1560-1570, doi:10.3155/1047-3289.58.12.1560, 2008.

Shen, Z., Cao, J., Arimoto, R., Han, Z., Zhang, R., Han, Y., Liu, S., Okuda, T., Nakao, S., and Tanaka, S.: Ionic composition of TSP and PM2.5 during dust storms and air pollution episodes at Xi' an, China, Atmos. Environ., 43, 2911-2918, doi:10.1016/j.atmosenv.2009.03.005, 2009.

Shrivastava, M. K., Lipsky, E. M., Stanier, C. O., and Robinson, A. L.: Modeling Semivolatile Organic Aerosol Mass Emissions from Combustion Systems, Environ. Sci. Technol., 40, 26712677, doi:10.1021/es0522231, 2006.

Shrivastava, M. K., Lane, T. E., Donahue, N. M., Pandis, S. N., and Robinson, A. L.: Effects of gas particle partitioning and aging of primary emissions on urban and regional organic aerosol concentrations, J. Geophys. Res., 113, D18301, doi:10.1029/2007JD009735, 2008.

Stein, U. and Alpert, P.: Factor Separation in Numerical Simulations, J. Atmos. Sci., 50, 2107-2115, doi:10.1175/15200469(1993)050<2107:fsins>2.0.co;2, 1993.

Strader, R.: Evaluation of secondary organic aerosol formation in winter, Atmos. Environ., 33, 4849-4863, doi:10.1016/s13522310(99)00310-6, 1999.

Sun, Y., Wang, Z., Dong, H., Yang, T., Li, J., Pan, X., Chen, P., and Jayne, J. T.: Characterization of summer organic and inorganic aerosols in Beijing, China with an Aerosol Chemical Speciation Monitor, Atmos. Environ., 51, 250-259, doi:10.1016/j.atmosenv.2012.01.013, 2012.

Sun, Y. L., Wang, Z. F., Fu, P. Q., Yang, T., Jiang, Q., Dong, H. B., Li, J., and Jia, J. J.: Aerosol composition, sources and processes during wintertime in Beijing, China, Atmos. Chem. Phys., 13, 4577-4592, doi:10.5194/acp-13-4577-2013, 2013.

Tie, X., Madronich, S., Walters, S., and Zhang, R.: Effect of clouds on photolysis and oxidants in the troposphere, J. Geophys. Res., 108, 4642, doi:10.1029/2003jd003659, 2003. 
Tie, X., Zhang, Q., He, H., Cao, J., Han, S., Gao, Y., Li, X., and Jia, X. C.: A budget analysis of the formation of haze in Beijing, Atmos. Environ., 100, 25-36, doi:10.1016/j.atmosenv.2014.10.038, 2015.

Tsimpidi, A. P., Karydis, V. A., Zavala, M., Lei, W., Molina, L., Ulbrich, I. M., Jimenez, J. L., and Pandis, S. N.: Evaluation of the volatility basis-set approach for the simulation of organic aerosol formation in the Mexico City metropolitan area, Atmos. Chem. Phys., 10, 525-546, doi:10.5194/acp-10-525-2010, 2010.

Volkamer, R., San Martini, F., Molina, L. T., Salcedo, D., Jimenez, J. L., and Molina, M. J.: A missing sink for gas-phase glyoxal in Mexico City: Formation of secondary organic aerosol, Geophys. Res. Lett., 34, L19807, doi:10.1029/2007GL030752, 2007.

Wesely, M. L.: Parameterization of surface resistances to gaseous dry deposition in regional-scale numerical models, Atmos. Environ., 23, 1293-1304, doi:10.1016/0004-6981(89)90153-4, 1989.

Yang, F., Tan, J., Zhao, Q., Du, Z., He, K., Ma, Y., Duan, F., Chen, G., and Zhao, Q.: Characteristics of $\mathrm{PM}_{2.5}$ speciation in representative megacities and across China, Atmos. Chem. Phys., 11, 5207-5219, doi:10.5194/acp-11-5207-2011, 2011.

Yu, X. Y.: Measurements of Carbonaceous Aerosols Using SemiContinuous Thermal-Optical Method, Integrated Waste Management - Volume I, edited by: Kumar, S., InTech., 521-538, 2011.

Yu, X.-Y., Cary, R. A., and Laulainen, N. S.: Primary and secondary organic carbon downwind of Mexico City, Atmos. Chem. Phys., 9, 6793-6814, doi:10.5194/acp-9-6793-2009, 2009.

Zhang, Q., Jimenez, J. L., Canagaratna, M. R., Allan, J. D., Coe, H., Ulbrich, I., Alfarra, M. R., Takami, A., Middlebrook, A. M., Sun, Y. L., Dzepina, K., Dunlea, E., Docherty, K., DeCarlo, P. F., Salcedo, D., Onasch, T., Jayne, J. T., Miyoshi, T., Shimono, A., Hatakeyama, S., Takegawa, N., Kondo, Y., Schneider, J., Drewnick, F., Borrmann, S., Weimer, S., Demerjian, K., Williams, P., Bower, K., Bahreini, R., Cottrell, L., Griffin, R. J., Rautiainen, J., Sun, J. Y., Zhang, Y. M., and Worsnop, D. R.: Ubiquity and dominance of oxygenated species in organic aerosols in anthropogenically-influenced Northern Hemisphere midlatitudes, Geophys. Res. Lett., 34, L13801, doi:10.1029/2007GL029979, 2007.
Zhang, Q., Streets, D. G., Carmichael, G. R., He, K. B., Huo, H., Kannari, A., Klimont, Z., Park, I. S., Reddy, S., Fu, J. S., Chen, D., Duan, L., Lei, Y., Wang, L. T., and Yao, Z. L.: Asian emissions in 2006 for the NASA INTEX-B mission, Atmos. Chem. Phys., 9, 5131-5153, doi:10.5194/acp-9-5131-2009, 2009.

Zhang, Q., Quan, J., Tie, X., Li, X., Liu, Q., Gao, Y., and Zhao, D.: Effects of meteorology and secondary particle formation on visibility during heavy haze events in Beijing, China, Sci. Total Environ., 502, 578-584, doi:10.1016/j.scitotenv.2014.09.079, 2015.

Zhang, R., Jing, J., Tao, J., Hsu, S.-C., Wang, G., Cao, J., Lee, C. S. L., Zhu, L., Chen, Z., Zhao, Y., and Shen, Z.: Chemical characterization and source apportionment of $\mathrm{PM}_{2.5}$ in Beijing: seasonal perspective, Atmos. Chem. Phys., 13, 7053-7074, doi:10.5194/acp-13-7053-2013, 2013.

Zhao, J., Levitt, N. P., Zhang, R., and Chen, J.: Heterogeneous Reactions of Methylglyoxal in Acidic Media: Implications for Secondary Organic Aerosol Formation, Environ. Sci. Technol., 40, 7682-7687, doi:10.1021/es060610k, 2006. 